\title{
The Role of Temperature in Shaping Mosquito-Borne Viruses Transmission
}

\author{
Rachel Bellone ${ }^{1,2}$ and Anna-Bella Failloux ${ }^{1 *}$ \\ ${ }^{1}$ Department of Virology, Arboviruses and Insect Vectors, Institut Pasteur, Paris, France, ${ }^{2}$ Sorbonne Université, Collège \\ Doctoral, Paris, France
}

Mosquito-borne diseases having the greatest impact on human health are typically prevalent in the tropical belt of the world. However, these diseases are conquering temperate regions, raising the question of the role of temperature on their dynamics and expansion. Temperature is one of the most significant abiotic factors affecting, in many ways, insect vectors and the pathogens they transmit. Here, we debate the veracity of this claim by synthesizing current knowledge on the effects of temperature on arboviruses and their vectors, as well as the outcome of their interactions.

OPEN ACCESS

Edited by:

Akio Adachi,

Kansai Medical University, Japan

Reviewed by:

Nicholas Johnson,

Animal and Plant Health Agency,

United Kingdom

Yan-Jang S. Huang,

Kansas State University, United States

Devin Kirk,

Stanford University, United States

*Correspondence:

Anna-Bella Failloux

anna-bella.failloux@pasteur.fr

Specialty section:

This article was submitted to

Virology,

a section of the journal

Frontiers in Microbiology

Received: 18 July 2020

Accepted: 07 September 2020

Published: 25 September 2020

Citation:

Bellone R and Failloux A-B (2020) The Role of Temperature in Shaping

Mosquito-Borne Viruses

Transmission.

Front. Microbiol. 11:584846

doi: 10.3389/fmicb.2020.584846
Keywords: temperature, arboviruses, vector-borne diseases, mosquitoes, vectorial capacity

\section{INTRODUCTION}

Viral pathogens with high epidemic potential have been historically a major concern for global economies and health. Over the past decades, efforts put into vaccination programs, alongside the development of effective antiviral treatments, have led to major medical advances. However, in a constantly changing world, viral diseases remain a major challenge; infectious agents continuously evolve and find opportunities to emerge (Malik Peiris and Parrish, 2011). Over time, vectorborne diseases (VBDs) have become increasingly important, reaching nearly $30 \%$ of emerging infectious disease events (Jones et al., 2008). More precisely, in the past 30 years, mosquitoborne viruses (MBVs) have dramatically expanded their distribution range within increasingly frequent and large epidemics (Gubler, 1996, 2002b; Mayer et al., 2017). MBVs such as Zika virus (ZIKV; Flaviviridae, Flavivirus), dengue virus (DENV; Flaviviridae, Flavivirus), yellow fever virus (YFV; Flaviviridae, Flavivirus), West Nile virus (WNV; Flaviviridae, Flavivirus), and chikungunya virus (CHIKV; Togaviridae, Alphavirus) have been responsible for millions of human cases with significant morbidity and mortality over the last decade (Gould et al., 2017; Figure 1).

In 2016, ZIKV was designated as a public health emergency of international concern by the World Health Organization (WHO). Indeed, 50 years after its first isolation from a human case in East Africa (Simpson, 1964; Gubler et al., 2017), ZIKV largely spread in the Pacific islands and the Americas accompanied by unusual notifications of microcephaly in newborns. The sudden and rapid spread of ZIKV received widespread media coverage, yet the upsurge or expansion of historical flaviviruses (YFV and DENV) is also of major importance and raises questions about our ability to eliminate arboviruses. DENV is one of the most widespread MBV with nearly half of the world's population (128 countries) at risk of infection (Brady et al., 2012; Messina et al., 2014); it affects annually 50-100 million people (Bhatt et al., 2013) at a cost of US\$ 8-9 billion (Shepard et al., 2016). While classic dengue fever occurs practically everywhere in the distribution range of its principal vector, Aedes aegypti, dengue hemorrhagic fever is more widespread in 


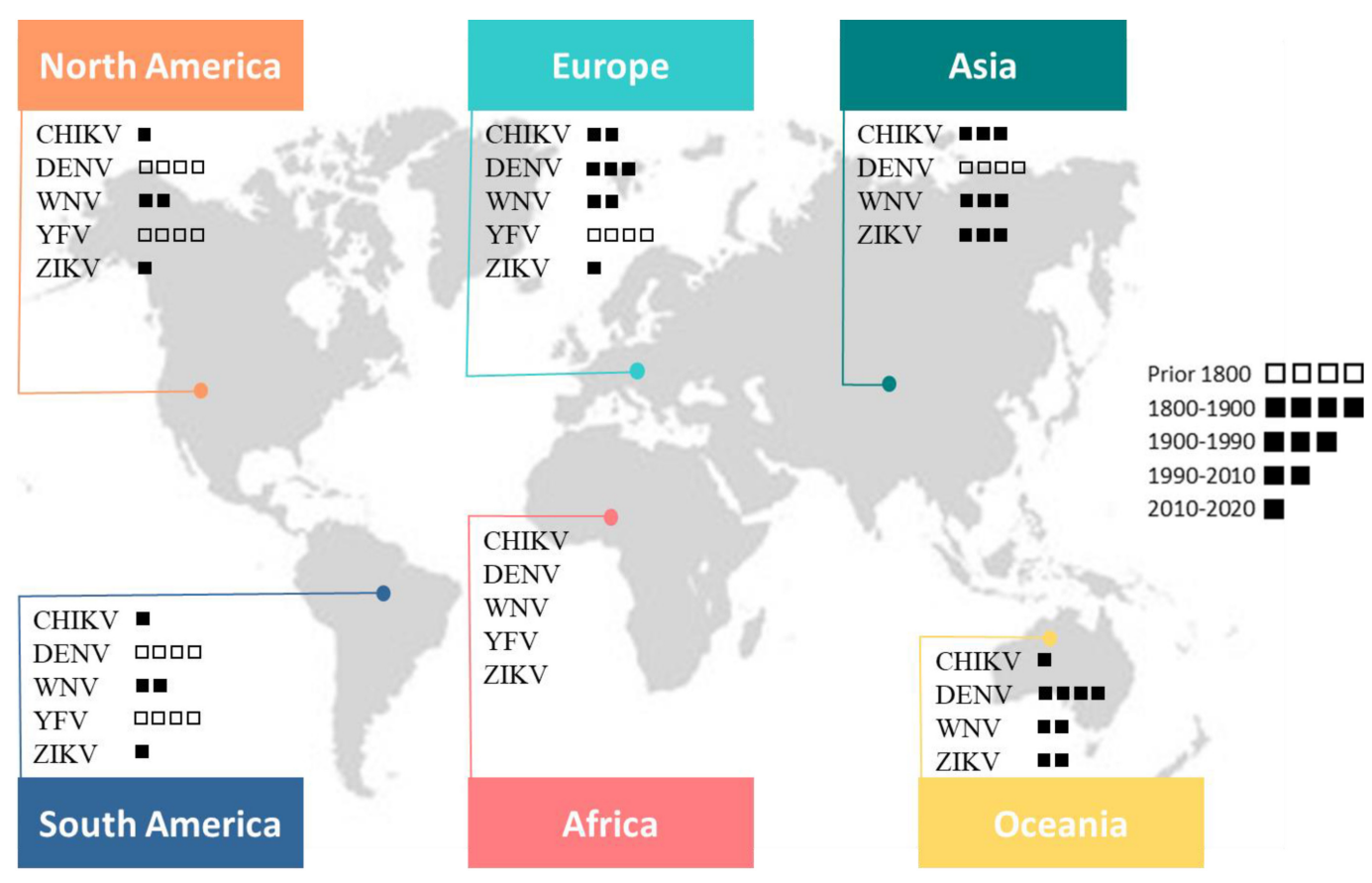

FIGURE 1 | This map shows the global distribution of five arboviruses (current or past local transmission). Little squares refer to the period of first documented detection in humans (virus introduction). Phylogenetic studies suggest an African origin for all five viruses (Braack et al., 2018).

South-East Asia and tropical America. In the absence of vaccines without restriction use and specific antiviral treatments, the dengue situation is worsening with a notable rise in mortality rates (Ong et al., 2007). In addition, YFV originated from Africa, caused devastating urban epidemics from the 18th to the early 20th century in the Americas (Monath and Vasconcelos, 2015). The development of vaccines in the 1930s as well as mosquito control programs led to an elimination of urban yellow fever. While YFV infections are now mainly acquired in the forest cycle, the number of urban human cases is increasing, evidencing a significant epidemiological change of yellow fever in South America (Vasconcelos and Monath, 2016). Another important member of the Flavivirus genus, WNV, transmitted by Culex species mosquitoes, gradually became the most widely distributed MBV (Chancey et al., 2015). In the late 1990s, the epidemiology and clinical spectrum of WNV remarkably changed. Notably, in 1999, from a small focus in New York City, WNV spread throughout the United States (US) accompanied by the detection of encephalitis cases. In the following years, the virus spread throughout the continent and in 2002, the United States recorded the largest outbreak of West Nile meningo-encephalitis ever documented in the world (Sejvar, 2003). The WNV outbreak in the United States (1999-2010) is a reminder that the importation and establishment of vector-borne pathogens outside their original distribution range represents a serious threat to the world ${ }^{1}$. Following the WNV episode, the American continent was again hit by another MBV in 2013; this time, it was an Alphavirus, the CHIKV. After decades of sporadic outbreaks in Africa and

${ }^{1}$ https://www.who.int/news-room/fact-sheets/detail/west-nile-virus
Asia, CHIKV finally emerged as a global pathogen causing large scale epidemics in Africa, Asia, America and to a lesser extent, in Europe (Zouache and Failloux, 2015; Silva and Dermody, 2017). CHIKV caused the first local Aedes albopictus-vectored virus transmission in Europe, with hundreds of cases in Italy and France (Grandadam et al., 2011; Calba et al., 2017; Rezza, 2018), less than 20 years after the first detection of Ae. albopictus in Italy (Sabatini et al., 1990). Later, Ae. albopictus was responsible for local cases of DENV and ZIKV in Croatia, France, and Spain (Gjenero-Margan et al., 2011; Aranda et al., 2018; Brady and Hay, 2019). The changing epidemiology of arboviral diseases results from a complex set of factors (Gubler, 2002a; Gould et al., 2017), combining both intrinsic and extrinsic interactions (Lambrechts et al., 2009; Zouache et al., 2014; Gloria-Soria et al., 2017).

In addition to human activities and globalization as key contributors in vector and pathogen spread, climate change exerts determinant effects on VBDs (Reeves et al., 1994; Gould and Higgs, 2009; Mills et al., 2010; IPCC, 2014). Because arthropods are poikilothermic ectotherms (i.e., body internal temperature is not constant and depends on temperature of surrounding environment), they are highly vulnerable to temperature changes, as are the pathogens they host. Environmental temperature is then, one of the most important abiotic factors influencing mosquito ecology, behavior, physiology and ultimately, virus transmission (Samuel et al., 2016; Reinhold et al., 2018). This review compiles the current knowledge on the effects of temperature on mosquito and virus biology with the goal of understanding how collectively these effects have an impact on virus-mosquito interactions and viral transmission. 


\section{MAIN FEATURES OF MOSQUITO-BORNE DISEASES}

\section{Clinical Aspects}

Most mosquito-borne viral infections are asymptomatic or non-specific mild infections (Endy et al., 2011). Symptomatic infections are often identified as a systemic febrile illness with non-specific symptoms, thus making mosquito-borne diseases (MBDs) very difficult to diagnose (Pezzi et al., 2019). Headache, weakness and rashes are common manifestations. Muscle and joint aches are also very frequent, especially with Alphavirus infections, for which these symptoms can persist for months or even years. In most cases, MBDs febrile illness ends with a full recovery. In only a few cases, illness may evolve to more severe forms, which principally include hepatonephritis, hemorrhagic fever, and encephalitis (Young, 2018). Currently, there are only two marketed vaccines [against YFV and Japanese encephalitis virus (JEV)] and treatments are not specific. It is worth mentioning that asymptomatic cases are epidemiologically important, although clinically unapparent. In absence of symptoms, people can still transmit the virus either because they have sufficient viremia to participate to the natural transmission cycle (Duong et al., 2015) or because of other transmission routes such as blood transfusion or organ transplantation (Chastel, 2011).

\section{Complex Transmission Cycles}

Mosquito-borne viruses circulate primarily within enzootic cycles between zoophilic mosquitoes and wild animals. Spillovers of enzootic viruses from a sylvatic cycle occur when anthropozoophilic mosquitoes serve as bridge vectors for transmission of the virus from animals to humans. It is then, an opportunity for the virus to enter epidemic cycles where mosquitoes are vectors and humans are either (i) dead-end host, because infection does not lead to a viremia high enough to infect mosquitoes [e.g., West Nile virus (WNV), Venezuelan equine encephalitis virus (VEEV) or JEV] or (ii) reservoir and amplification host, when infection in humans leads to high viremia, ensuring an inter-human transmission (e.g., DENV, ZIKV, CHIKV, and YFV) (Young, 2018; Valentine et al., 2019). In the first scheme, epidemics rely on regular virus spillover from enzootic cycles while in the second scheme, epidemic cycles are self-sustaining, having lost the requirement of enzootic cycles to cause outbreaks (Weaver and Reisen, 2010). Some transmission cycles may be relatively simple with a main vector and a main host species (e.g., DENV, CHIKV, and ZIKV), while some others are more complex, involving several host and vector species [e.g., Rift Valley Fever Virus (RVFV), JEV, WNV] (Young, 2018).

\section{VIRUS CYCLE IN THE VECTOR AND EFFECTS OF TEMPERATURE}

Mosquito-borne viruses are arthropod-borne viruses (arboviruses), a group of viruses typically transmitted from infected to susceptible vertebrate hosts by hematophagous arthropods (vectors). Most arboviruses causing human diseases belong to three main families: Flaviviridae (genus Flavivirus), Togaviridae (genus Alphavirus) and Phenuiviridae (genus Phlebovirus). These viruses share different types of genomes, structural organization and replication strategies (Holmes, 2003; Duffy et al., 2008; Bradwell et al., 2013), but have in common, single stranded RNAs as carriers of their genetic information.

\section{Characteristics of RNA Genomes}

Because of their chemical structures, RNAs appears as an unreliable support for transmission of genetic information in comparison to DNA (Lindahl, 1996; Lazcano et al., 1988; Krokan et al., 2002). A striking attribute of RNA viruses is their high mutation rate. During RNA replication, the mutational rate is in the range of $10^{-6}$ to $10^{-4}$ substitutions per nucleotide, corresponding roughly to 0.01 to 1 mutation per $10 \mathrm{~kb}$ of genome (Domingo and Holland, 1997; Lauring et al., 2013). This high mutation rate greatly contrasts with that of prokaryotic or eukaryotic genomes (Drake et al., 1998; Drake, 1999; Nachman and Crowell, 2000), as well as with that of DNA viruses (range of $10^{-8}$ to $10^{-6}$ ) (Sanjuan et al., 2010). The high fidelity of DNA replication is not merely insured by the accuracy of DNA polymerases but also by the combined action of proofreading enzymes and mismatch repair system (Sanjuan and Domingo-Calap, 2016). The absence of such correction activity during RNA replication results in a more error-prone replication mode (Steinhauer et al., 1992). Consequently, RNA viruses circulate as dynamic mutant clouds of closely related genome sequences referred to as a quasispecies (Domingo et al., 2008). In the multi-component viral system, replicative infectious particles coexist with defective genomes, including defective interfering genomes (DIs) that are degenerated and non-replicative forms of viral genomes. DIs depend on the co-infection with the self-infectious virus for replication and play a significant role in triggering immune responses, modulating disease outcome and influencing virus replication and evolution (Rezelj et al., 2018). High mutation rates and short generation times are largely responsible for the extremely high genetic variability of RNA virus populations (Moya et al., 2000). Other source of variation in RNA viruses include recombination and reassortment (Domingo and Holland, 1997). Overall, RNA virus populations behave as huge reservoirs of mutants that permit rapid adaptation to environmental changes. In the mutant cloud, sequences are subject to constant genetic changes, competition and selection for the most suitable combination of viral genomes (Andino and Domingo, 2015; Domingo and Perales, 2019). RNA viruses can then exploit multiple adaptive solutions to overcome selective pressures such as immune responses, antiviral therapies or fluctuating environments.

\section{Dual Host Cycling and Virus Adaptation}

Despite inherent potential for mutation and subsequent adaptation, arboviruses exhibit lower mutational rates than non-vectored RNA viruses (by a factor of 10) (Jenkins et al., 2002; Vasilakis et al., 2009). This evolutionary stasis is generally attributed to the alternated transmission between 
hosts belonging to two disparate phyla, each of which presenting different demands for viral replication. According to the trade-off hypothesis, the virus is constrained to a compromised fitness for an optimal replication in both vector and vertebrate hosts (Coffey et al., 2008; Ciota and Kramer, 2010), although this explanation is not always well supported by other studies (Novella et al., 1999; Ciota et al., 2009; Deardorff et al., 2011).

Transmission occurs when the virus ingested by the vector replicates successfully in midgut epithelial cells, peripheral tissues/organs and salivary glands, prior to its expectoration through the insect bite (Figure 2). During this journey in the vector, viral populations undergo successive genetic bottlenecks that greatly modify initial population structures (Forrester et al., 2014). A study performed with DENV-2 showed that more than $90 \%$ of single nucleotide variants (SNVs) were lost upon transmission from infected patients to Ae. aegypti mosquitoes, as well as from mosquito midgut to salivary glands; new variants were generated at each step of infection in vector, thereby maintaining the level of viral diversity (Coffey et al., 2013; Sim et al., 2015). Bottlenecks encountered by viruses differ according to mosquito species and probably, mosquito-virus combinations (Grubaugh et al., 2016). Viruses are thus exposed to the specific selective pressures

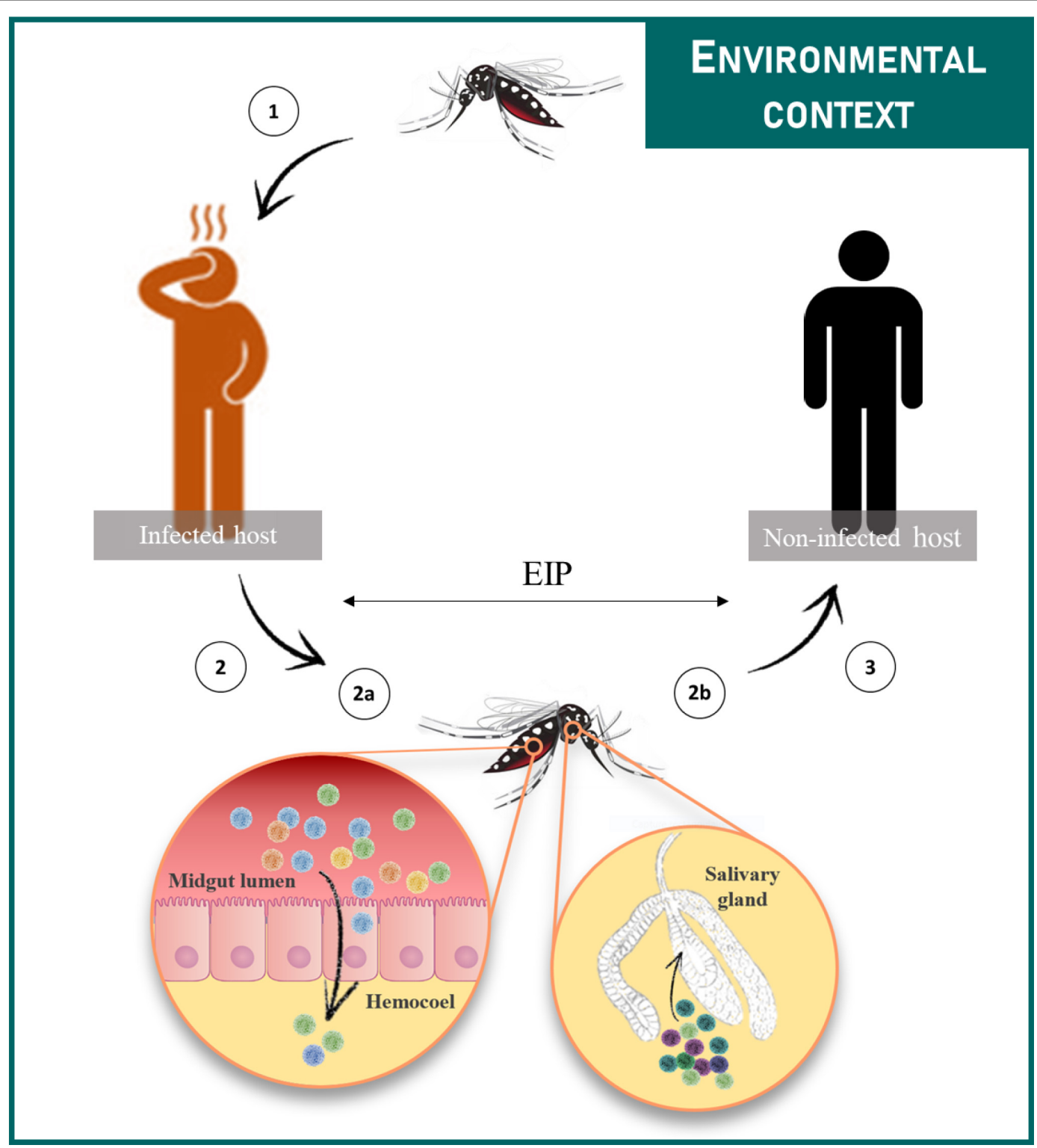

FIGURE 2 | Female mosquitoes acquire the virus during a blood meal on a viremic host (1). Then the virus infects the midgut epithelium from which it escapes and disseminates to peripheral tissues/organs (2a). The virus reaches the salivary glands (2b) in which it replicates prior to be released in saliva during a blood meal (3). The time between the ingestion of the virus and its presence in saliva is referred to as the EIP. Transmission cycles are influenced by multiple extrinsic environmental factors. 
of their hosts. These selective pressures, including virus entry (appropriate receptors), microbiota and immune responses, directly shape virus evolutionary patterns and ultimately, their potential to emerge (Ruckert and Ebel, 2018). For instance, the adaptive amino acid change from alanine to valine at the position 226 of the E1 glycoprotein (E1-A226V) of the East/Central/South African (ECSA) CHIKV arose from an unusual transmission by Ae. albopictus instead of the classical vector Ae. aegypti. This specific mutation led to an enhanced transmission of CHIKV by Ae. albopictus (Tsetsarkin et al., 2007; Vazeille et al., 2007) causing 266000 human cases during the 2005-2006 epidemic on La Réunion island (Schuffenecker et al., 2006). However, the benefit of the E1-A226V mutation in Ae. albopictus may vary according to the environmental temperature (Zouache et al., 2014). As vectors are exposed to a multitude of environmental variables, which can modify their intrinsic properties, consequences on viral populations are expected; viral populations may explore possibilities of adaptation and thus follow evolutionary processes associated with molecular and phenotypic changes (Ciota and Kramer, 2010; Coffey et al., 2013).

\section{Effects of Temperature on Viral Populations}

In their vertebrate host, arboviruses replicate at temperatures ranging from $37^{\circ} \mathrm{C}$ up to $44^{\circ} \mathrm{C}$ (Kinney et al., 2006), then switch to their ectotherm vectors where temperatures vary depending on the ambient temperature (as low as $\sim 15^{\circ} \mathrm{C}$; Table 1). The fact that arboviruses tolerate such drastic temperature changes raises a number of questions: the effects of temperature on quasispecies structures and dynamics, the selection of temperature-adapted variants and impacts on virus transmission, expansion and pathogenesis. Temperature is known to induce molecular changes that impact lipids, nucleic acids and protein structures and functions (Pain, 1987). Temperature is thus very likely to modify properties of virions and their interactions with cellular components during replication. Studies on enzyme

TABLE 1 | Effect of temperature on vector competence.

\begin{tabular}{|c|c|c|c|c|c|}
\hline Virus strains & $\begin{array}{l}\text { Mosquito } \\
\text { Species }\end{array}$ & $\begin{array}{l}\text { Mosquito } \\
\text { populations }\end{array}$ & Temperatures & Results & References \\
\hline \multicolumn{6}{|l|}{ DENV } \\
\hline $\begin{array}{l}\text { DENV-2 (New } \\
\text { Guinea C) }\end{array}$ & Ae. albopictus & China (Foshan) & $\begin{array}{l}18,23,28, \text { and } \\
32^{\circ} \mathrm{C}\end{array}$ & EIP was shorter at the highest temperature & Liu et al., 2017 \\
\hline $\begin{array}{l}\text { DENV-2 (New } \\
\text { Guinea C) }\end{array}$ & Ae. albopictus & China (Shangai) & $\begin{array}{l}18,21,26,31 \\
\text { and } 36^{\circ} \mathrm{C}\end{array}$ & $\begin{array}{l}\text { EIP gradually decreased when temperature increased. Infection rates } \\
\text { increased along with temperature until } 31^{\circ} \mathrm{C}\end{array}$ & $\begin{array}{l}\text { Xiao et al., } \\
2014\end{array}$ \\
\hline $\begin{array}{l}\text { DENV-2 (Kenya, } \\
\text { 2012) }\end{array}$ & Ae. aegypti & $\begin{array}{l}\text { Kenya (Kilifi and } \\
\text { Nairobi) }\end{array}$ & 26 and $30^{\circ} \mathrm{C}$ & Infection rates were higher at $30^{\circ} \mathrm{C}$ & $\begin{array}{l}\text { Chepkorir et al., } \\
2014\end{array}$ \\
\hline $\begin{array}{l}\text { DENV-2 }(434 S \\
\text { and } 6 \mathrm{H})\end{array}$ & Ae. aegypti & $\begin{array}{l}\text { Vietnam (Hanoi } \\
\text { and Ho Chi Minh) }\end{array}$ & 25,27 , and $32^{\circ} \mathrm{C}$ & $\begin{array}{l}\text { The mosquito population from Ho Chi Minh City was more susceptible } \\
\text { to infection at lower temperature than the mosquito population from } \\
\text { Hanoi. For both virus strains, highest infection rates were obtained at } \\
25^{\circ} \mathrm{C} \text { for the mosquito population from Ho Chi Minh City }\end{array}$ & $\begin{array}{l}\text { Gloria-Soria } \\
\text { et al., } 2017\end{array}$ \\
\hline \multicolumn{6}{|l|}{ ZIKV } \\
\hline $\begin{array}{l}\text { Asian lineage } \\
\text { (PRVABC59) }\end{array}$ & Ae. aegypti & $\begin{array}{l}\text { United States } \\
\text { (California) }\end{array}$ & $\begin{array}{l}18,21,26, \text { and } \\
30^{\circ} \mathrm{C}\end{array}$ & $\begin{array}{l}\text { EIP decreased as temperature increased. At } 18^{\circ} \mathrm{C} \text {, a } 15 \% \\
\text { transmission efficiency was reached at day } 31 \text { post infection (pi), } \\
\text { while a } 100 \% \text { transmission was observed at } 21 \text { days pi at } 30^{\circ} \mathrm{C}\end{array}$ & $\begin{array}{l}\text { Winokur et al., } \\
2020\end{array}$ \\
\hline $\begin{array}{l}\text { Asian lineage } \\
\text { (FB-GWUH-2016) }\end{array}$ & Ae. japonicus & Germany & 21,24 , and $27^{\circ} \mathrm{C}$ & $\begin{array}{l}\text { Infection rates increased with temperature and virus transmission was } \\
\text { detected exclusively at } 27^{\circ} \mathrm{C}\end{array}$ & $\begin{array}{l}\text { Jansen et al., } \\
2018\end{array}$ \\
\hline \multicolumn{6}{|l|}{ WNV } \\
\hline WN-FL03p2-3 & $\begin{array}{l}\text { Cx. } \\
\text { quinquefasciatus }\end{array}$ & $\begin{array}{l}\text { United States } \\
\text { (Florida) }\end{array}$ & 25,28 , and $30^{\circ} \mathrm{C}$ & Infection rates increased as temperature increased & $\begin{array}{l}\text { Richards et al., } \\
2007\end{array}$ \\
\hline $\begin{array}{l}\text { NY99_crow } \\
397-99\end{array}$ & Cx. pipiens & $\begin{array}{l}\text { United States } \\
\text { (New-York) }\end{array}$ & $\begin{array}{l}18,20,26 \text {, and } \\
30^{\circ} \mathrm{C}\end{array}$ & Infection rates increased as temperature increased & $\begin{array}{l}\text { Dohm et al., } \\
2002\end{array}$ \\
\hline $\begin{array}{l}\text { NY99-3356 and } \\
\text { WN02-1956 }\end{array}$ & Cx. pipiens & $\begin{array}{l}\text { United States } \\
\text { (Pennsylvania) }\end{array}$ & $\begin{array}{l}15,18,22, \text { and } \\
32^{\circ} \mathrm{C}\end{array}$ & EIP was significantly shorter and transmission rates higher at $32^{\circ} \mathrm{C}$ & $\begin{array}{l}\text { Kilpatrick et al., } \\
2008\end{array}$ \\
\hline $\begin{array}{l}\text { WNV lineage } 2 \\
\text { (Greece 2010) }\end{array}$ & Cx. pipiens & $\begin{array}{l}\text { Netherlands } \\
\text { (Amsterdam } \\
\text { and Best) }\end{array}$ & 18,23 . and $28^{\circ} \mathrm{C}$ & $\begin{array}{l}\text { Biotype pipiens and hybrids showed significant increased } \\
\text { transmission rates at higher temperatures. Biotype molestus } \\
\text { transmission rate did not increase with temperature }\end{array}$ & $\begin{array}{l}\text { Vogels et al., } \\
2016\end{array}$ \\
\hline \multicolumn{6}{|l|}{ CHIKV } \\
\hline $\begin{array}{l}\text { ECSA; (Mauritius, } \\
\text { 2006) Asian; } \\
\text { (Caribbean, 2014) }\end{array}$ & Ae. albopictus & Australia & 18 and $28^{\circ} \mathrm{C}$ & $\begin{array}{l}\text { EIP was shorter at } 28^{\circ} \mathrm{C} \text {. At } 18^{\circ} \mathrm{C} \text {, mosquitoes infected with the Asian } \\
\text { genotype showed no evidence of virus in saliva even at the latest } \\
\text { analysis time point ( } 7 \text { days post infection) }\end{array}$ & $\begin{array}{l}\text { Wimalasiri- } \\
\text { Yapa et al., } \\
2019\end{array}$ \\
\hline $\begin{array}{l}\text { ECSA } \\
\text { (CNR_24/2014) }\end{array}$ & Ae. albopictus & Germany, Italy & 18,21 , and $24^{\circ} \mathrm{C}$ & Transmission rates were higher at lower temperatures & $\begin{array}{l}\text { Heitmann et al., } \\
2018\end{array}$ \\
\hline ECSA (Lamu001) & Ae. aegypti & $\begin{array}{l}\text { Kenya (Western } \\
\text { and Coastal } \\
\text { regions) }\end{array}$ & 26 and $32^{\circ} \mathrm{C}$ & $\begin{array}{l}\text { Western mosquitoes exhibited higher infection rates at } 32^{\circ} \mathrm{C} \text { than at } \\
26^{\circ} \mathrm{C} \text {. In contrast, coastal mosquitoes did not show any statistical } \\
\text { difference in infection rates whatever the temperature }\end{array}$ & $\begin{array}{l}\text { Mbaika et al., } \\
2016\end{array}$ \\
\hline
\end{tabular}


functional attributes most sensitive to temperature indicate that ligand binding affinity and catalytic rate are key targets during temperature adaptation; ligand affinity decreases during cold adaptation to allow more rapid catalysis (Fields et al., 2015). Whereas, thermodynamic models suggest that at low temperatures, enhanced cell binding may compensate for lower replication kinetic rates such that some transmission can still occur (Gale, 2019). Some DENV serotypes undergo a temperature dependent conformational change from a "smooth" form at lower temperatures to a "bumpy" form at temperatures approaching $37^{\circ} \mathrm{C}$ (Rey, 2013; Zhang et al., 2015). In addition, alphaviruses were found to enter mammalian cells via a temperature-dependent alternative mechanism. At temperatures that inhibit virus receptor-mediated endocytosis (classical entry for arboviruses), viral genomes were internalized directly at the plasma membrane (Vancini et al., 2013). Furthermore, silent mutations (i.e., mutations without amino acid sequence changes) are believed to play important roles in adaptation of RNA virus to elevated temperature (Kashiwagi et al., 2014). Temperature could influence the incidence and severity risk of arboviruses outbreaks by altering arboviruses evolution, selection and transmission.

\section{MOSQUITO BIOLOGY, PHYSIOLOGY, BEHAVIOR AND EFFECTS OF TEMPERATURE}

Mosquitoes are the principal vector of arboviruses, although other arthropod taxa such as ticks, sandflies and biting midges are also implicated in medically important arboviruses transmission (Alkan et al., 2013; Kazimirova et al., 2017; Sick et al., 2019). Mosquitoes have a complex life cycle characterized by complete metamorphosis and four distinct life stages: egg, larva, pupa and adult. The first three stages occur in water whereas adults are active flying insects, with females being hematophagous. The period between blood feeding and eggs laying corresponds to the gonotrophic cycle; females undergo successive gonotrophic cycles during their entire life.

\section{Effects of Temperature on Mosquito Distribution and Life History Traits}

Environmental temperature is an overriding factor defining the geographic distribution range limits of many organisms, in particular ectotherms. Mosquitoes can only survive and reproduce in suitable environments that depend on the ecological characteristics of the mosquito species. Many studies have used temperature to map global or regional suitability and distribution of mosquito species (Nawrocki and Hawley, 1987; Brady et al., 2013, 2014; Samy et al., 2016; Ding et al., 2018). With their model, Kraemer et al. (2015) estimated Ae. aegypti and Ae. albopictus distributions to be now extensive in all continents, including North America and Europe. For both species, the most important predictor of distribution was temperature (Kraemer et al., 2015). Sensitivity of mosquitoes to temperature reflects the effects of temperature on the main mosquito physiological processes.
First, temperature has a significant effect on eggs viability and hatching time, with optimal temperatures for hatching depending on mosquito species (Hawley et al., 1989; Hanson and Craig, 1994; Impoinvil et al., 2007; Mohammed and Chadee, 2011). Eggs of the temperate mosquito, Ae. albopictus, tolerate lower temperatures than eggs of tropical Ae. aegypti (Hanson and Craig, 1994); this contributes significantly to the larger geographical distribution of Ae. albopictus encompassing both tropical and temperate regions (Kraemer et al., 2015). Besides, eggs of Ae. albopictus from temperate regions have lower lethal temperatures than eggs of the same species from tropical regions (Hanson and Craig, 1995), emphasizing thermal acclimation. Along with photoperiod, cold temperatures trigger the production of diapausing eggs in Ae. albopictus. Diapause is a genetically programmed mechanism crucial for mosquitoes to overwinter (Thomas et al., 2012); it is a hormonally controlled developmental arrest that is triggered by unfavorable environmental conditions and lifted with the return of favorable conditions (Denlinger and Armbruster, 2014).

Secondly, larvae and pupae are strictly aquatic stages and thus submitted to temperature variations of breeding sites. In addition to other factors such as nutrient availability, competition for food, presence of predators/parasites, pollution with organic matter and chemicals, temperature is critical for the survival, development and emergence time of immature stages (TunLin et al., 2000; Bayoh and Lindsay, 2004; Delatte et al., 2009; Dodson et al., 2012). Notably, survival of immature stages was compromised below $16^{\circ} \mathrm{C}$ and above $38^{\circ} \mathrm{C}$ for Ae. aegypti with an optimal survival rate at $26^{\circ} \mathrm{C}$ (Carrington et al., 2013). It is commonly found that as temperature increases, immature stages development time decreases (Shelton, 1973; Loetti et al., 2011; Dodson et al., 2012; Grech et al., 2015), up to a critical thermal threshold for survival (Delatte et al., 2009; Loetti et al., 2011). Development time of Ae. aegypti (from egg to adult) was inversely proportional to temperature, ranging from 7.2 days at $35^{\circ} \mathrm{C}$ to 39.7 days at $15^{\circ} \mathrm{C}$ (Tun-Lin et al., 2000). In addition, temperature stress during immature stages have carry-over effects on adult life traits such as fecundity, survival (Ezeakacha and Yee, 2019) and body size, with cooler temperatures producing larger mosquitoes (Mohammed and Chadee, 2011; Dodson et al., 2012). Correlations between body size and other physiological features such as blood feeding behavior have been largely discussed (Xue et al., 1995; Scott et al., 2000; Farjana and Tuno, 2013). Small mosquitoes presented exacerbated host-seeking behavior with multiple attempts to blood feed, enhancing contact frequency with hosts (Farjana and Tuno, 2013) while conflicting results were obtain elsewhere (Xue et al., 1995).

Regardless of temperature stress encountered during immature stages, temperature also has a direct impact on mosquito adult stage. In Culex species, female longevity significantly increased when adult holding temperature decreased (Ciota et al., 2014). Similarly, Ae. albopictus adult survival was inversely correlated with temperature, presenting the highest survival rate at $15^{\circ} \mathrm{C}$ and the lowest at $35^{\circ} \mathrm{C}$ (Delatte et al., 2009). Mosquito flight activity is important for many life history traits such as reproduction, nutrition and host-seeking. Ae. aegypti is able to fly in a temperature range of 15 to $32^{\circ} \mathrm{C}$ with an optimum 
at $21^{\circ} \mathrm{C}$ (Rowley and Graham, 1968). The gonotrophic cycle length is an indicator of mosquito abundance and a proxy of contact frequencies between hosts and vectors. The shorter the gonotrophic cycle, the more often females will come in contact with their hosts and the more generations will be produced, resulting in higher mosquito densities and greater population genetic diversity (increased potential to adapt to contrasting environments). In Ae aegypti, the duration of the gonotrophic cycle decreases when temperature increases. Temperature also influences the time for the first blood meal; females kept at higher temperatures have their first blood meal within $48 \mathrm{~h}$ of emergence. Finally, temperature had a significant effect on the number of eggs laid that peaks at nearly 80 eggs per female when reared at $26^{\circ} \mathrm{C}$ (Carrington et al., 2013).

It is noteworthy to mention that results obtained under constant temperatures can vary from those under fluctuating temperatures that better mimic field conditions. Temperature effects on life history traits like adult reproduction, larval survival and development time depend on the combination of mean temperature and magnitude of fluctuations (Lambrechts et al., 2011; Carrington et al., 2013; Liu-Helmersson et al., 2014).

\section{Effects of Temperature on Microbiota}

Mosquitoes harbor very complex, abundant and dynamic microbial communities that are found at high concentrations in the different intestinal portions (Dillon and Dillon, 2004; Engel and Moran, 2013). These micro-organisms are comprised of protozoans, fungi, bacteria and viruses (Guegan et al., 2018b; Strand, 2018). The combination of the host and its associated microbiota is referred to as the holobiont. This concept, where macro-organisms and their microbiota are seen as a cooperative unit, highlights the strong symbiotic interactions within the holobiont. Most of the literature focuses on bacterial communities, which were shown to play a major role in insect biology (contribution to nutrition, protection against pathogens, modulation of immune responses) (Engel and Moran, 2013; Guegan et al., 2018a; Sicard et al., 2019). While mosquitoes naturally host multiple bacteria [genera Acinetobacter, Asaia, Delftia, Pseudomonas, Wolbachia, Bacillus (Zouache et al., 2011)], their role in priming the mosquito immune responses is largely debated; the mosquito's microbiota elicits basal immune responses which act against pathogens and reduce density of the midgut microbial load itself (Ramirez et al., 2012). Temperature is a substantial factor shaping microbial communities of organisms, especially in insects (Prado et al., 2010; Lokmer and Mathias Wegner, 2015; Kikuchi et al., 2016; Moghadam et al., 2018). It was shown in flies that developmental temperature is a decisive factor influencing bacterial community structures with consequences on the flies' thermal tolerance (Moghadam et al., 2018). Similarly, in mosquitoes, temperature may affect midgut microbial diversity and structure. Compositional changes in Ae. albopictus midgut microbiota were found to be induced by a temperature decrease (Guegan et al., 2018a). Furthermore, higher temperatures were shown to reduce Wolbachia abundance in Culex pipiens/restuans mosquitoes, which in turn, was correlated with a higher susceptibility to WNV in subsequent mosquito generations and higher prevalence of the virus (Novakova et al., 2017).

\section{Effects of Temperature on Mosquito Gene Expression and Immunity}

Regulation of gene expression is a common mechanism that organisms use to adapt their phenotypes and maintain fitness in response to stressors such as temperature (Pigllucci, 1996; Morris and Rogers, 2014). Ae. aegypti adult mosquitoes held at $20^{\circ} \mathrm{C}$ had a very different transcriptomics profile from those held at $28^{\circ} \mathrm{C}$, whereas at a higher temperature $\left(36^{\circ} \mathrm{C}\right)$, mosquitoes showed no significant transcriptional differences from the standard holding temperature of $28^{\circ} \mathrm{C}$ (Gonçalves Ferreira et al., 2020). Genes, whose expression were altered at $20^{\circ} \mathrm{C}$, are involved in various aspects of mosquito biology: blood-meal digestion, ROS metabolism and mosquito innate immunity (Gonçalves Ferreira et al., 2020). Mosquito immunity constitutes a powerful protection in symbiotic, entomopathogenic and mosquito-borne pathogen infections. To defend against pathogens, mosquitoes activate several immune-signaling pathways: Toll, JAK-STAT, Imd/JNK and RNAi (RNA interference) pathways (Fragkoudis et al., 2009; Kumar et al., 2018). Temperature has complex effects on mosquito immune functions (Murdock et al., 2012). In Ae. aegypti, a differential expression of immune-specific and detoxification genes was found in fourth instar larvae exposed to temperature stress $\left(32^{\circ} \mathrm{C}\right)$. Thermal stress undergone during larval development had also remnant effects on adults' genes expression levels (Muturi et al., 2011). RNAi is the most significant antiviral immune response in mosquitoes (Blair, 2011). The triggering of the RNAi pathways can be destabilized when mosquitoes are reared at cooler temperatures $\left(18^{\circ} \mathrm{C}\right)$ (Adelman et al., 2013). Impairment of immune barriers may profoundly affect mosquito interactions with symbionts, entomopathogenic organisms and mosquito-borne pathogens but also interactions of these latter together. Studies have correlated the alteration of the immune system by thermal stress with changed susceptibility to CHIKV, YFV, and Sindbis virus (SINV) (Muturi et al., 2011; Adelman et al., 2013). The subtle balance between effects of temperatures on mosquito antiviral immune responses and virus replication likely conditions the outcome of virus transmission.

Collectively, by affecting mosquito biology, physiology and behavior, temperature plays a key role in mosquito dynamics (El Moustaid and Johnson, 2019). Changes in mosquito geographical distribution, survival, development time, gonotrophic cycle, microbiota or immune responses can have critical impacts on their role as vector of pathogens (Waldock et al., 2013a; da Cruz Ferreira et al., 2017).

\section{TEMPERATURE AND ITS POTENTIAL TO INFLUENCE ARBOVIRUSES TRANSMISSION}

\section{Major Concepts in Medical Entomology}

Arboviruses emergence is driven by the need of their arthropod vectors to uptake blood from vertebrate hosts. During a blood meal on a viremic host, female mosquitoes ingest the virus along with the blood. To transmit the virus to following hosts, the 
mosquito has to be competent for the virus (Figure 2). A key concept in medical entomology, vector competence is defined as the ability of an arthropod vector to uptake and transmit afterward a given pathogen (Hardy et al., 1983). In mosquitoes, it is generally determined by the crossing of four major barriers: (Malik Peiris and Parrish, 2011) the midgut infection barrier, (Jones et al., 2008) the midgut escape barrier, (Gubler, 1996) the salivary gland infection barrier and (Gubler, 2002b) the salivary gland escape barrier (Franz et al., 2015). Basically, the virus infects and replicates in the midgut epithelium before crossing the midgut basal lamina and disseminates to peripheral tissues/organs. Ultimately, the virus reaches the salivary glands in which it replicates prior to be released in the saliva (Figure 2). Competent females develop persistent infections, thus transmitting the virus for the rest of their lives at each blood meal on susceptible hosts via the injection of infectious saliva. Vector competence is controlled by both intrinsic (i.e., microbiota, mosquito and virus genetic) (Hardy et al., 1983; Lambrechts et al., 2009; Jupatanakul et al., 2014; Hegde et al., 2015; Houe et al., 2019) and extrinsic (i.e., temperature) factors (Zouache et al., 2014; Ciota et al., 2018). The concept of vector competence is integrated in a broader one that is vectorial capacity which is an epidemiological measure of the transmissibility of an infectious agent by a particular vector species/population in the field (Macdonald, 1957). The mathematical equation used to evaluate the vectorial capacity (Figure 3 ) includes the following parameters: vector-host ratio ( $\mathrm{m})$, mosquito biting rate on human (a), daily survival rate (p), infectiousness of the mosquito to the vertebrate host (b), susceptibility of the vertebrate host to the virus (c), extrinsic incubation period (n) and vertebrate host infectious period (1/r) (Fontenille and Powell, 2020). Factors influencing the vectorial capacity have been largely discussed (Kramer and Ciota, 2015); the most determining variables are mosquito survival rate and extrinsic incubation period (EIP). The EIP equals the time required between the ingestion of a virus and the ability of the vector to transmit it. When this period increases, the vectorial capacity decreases. All else being equal, a virus that takes 3 days to be transmitted versus one that takes 10 days within the same vector will have a much higher epidemic potential. Indeed, the shorter the EIP, the more likely the virus is transmitted before the vector dies.

\section{Effects of Temperature on Vectorial Capacity}

Temperature can affect important parameters of the vectorial capacity (Figure 3). First, the mosquito density, which relies on temperature-sensitive life-history traits like reproduction, gonotrophic cycles and developmental time, determines contact rates between hosts and vectors. For example, in a location where mosquitoes are at high densities, contacts between mosquitoes and hosts are increased, and so is pathogen transmission risk (Honorio et al., 2009). Second, the biting rate includes mosquito trophic preferences and requires an active host-seeking behavior which includes temperature-sensitive parameters (flight activity, gonotrophic cycle). Highly anthropophilic and active mosquitoes are more prone to transmit human pathogens and ensure their propagation. Third, mosquito survival, often negatively correlated with temperature, increases the time during which infected females serve as vectors (Christofferson and Mores, 2016). Older females are often considered as more epidemiologically dangerous, as they are more likely to have been infected and to subsequently, transmit the virus during their lifetime. Lastly, vector competence and EIP result from a complex combination of many intrinsic factors such as virus dynamics, virus and vector genetic, vector physiological traits, microbiota and immunity. Vector competence and EIP depends strongly and unimodally on temperature. Thermal optima and limits of transmission vary across vector-pathogen systems (Mordecai et al., 2019). By affecting major components
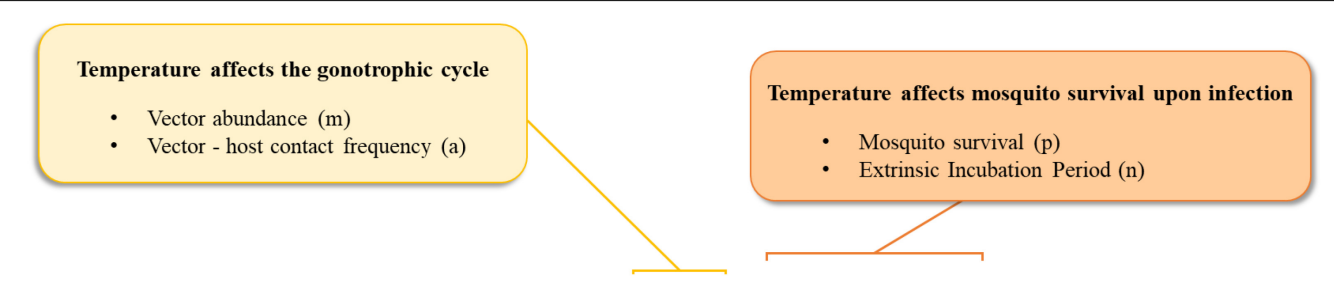

Vectorial capacity $=\left(m a^{2} \times p^{n} /-\ln p\right) \times b c \times 1 / r$

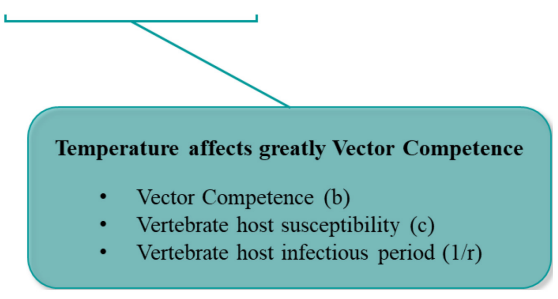

FIGURE 3 | The vectorial capacity represents the number of potential infectious bites that a vector dispenses after the EIP is completed. It describes the efficiency at which a vector population transmits a pathogen in natural settings. Temperature is a key factor affecting major parameters in this equation. 
of vectorial capacity, temperature may tip the scales toward either an increase or a decrease of arbovirus transmission potential.

\section{Principal Temperature-Dependent Factors Influencing MBV Transmission}

First described as temperature dependent by Davis in 1932 (Davis, 1932), EIP is often used as an index of vector competence. Higher temperatures are associated with reduced EIP and enhanced vector competence in many virus-vector pairings (Chamberlain and Sudia, 1955; Richards et al., 2007; Xiao et al., 2014; Liu et al., 2017; Wimalasiri-Yapa et al., 2019; Winokur et al., 2020). Virus replication rates generally increase with temperature, and since dissemination and transmission correlate with viral load (Kramer and Ciota, 2015), lower temperature is generally less advantageous for arbovirus transmission. However, some exceptions sprinkle the literature; $C x$. tarsalis mosquitoes, for example, were less competent for Western Equine Encephalitis Virus (WEEV) at $32^{\circ} \mathrm{C}$ than at lower temperatures $\left(18\right.$ and $25^{\circ} \mathrm{C}$ ) (Kramer et al., 1983). Likewise, higher infection and transmission rates were detected at lower temperature in Ae. aegypti infected with DENV (Heitmann et al., 2018) and in Ae. albopictus infected with CHIKV (Heitmann et al., 2018), respectively. These conflicting evidences are likely to result from disparate effects of temperature on virus replication and vector immune responses in each virus-vector combination.

Thermal exposure undergone during larval development has remnant effects on mosquito susceptibility to virus infection (Turell, 1993; Alto and Bettinardi, 2013). Immature stages of Ae. albopictus reared at lower temperatures gave adults with decreased viral dissemination when orally infected with DENV1 (Alto and Bettinardi, 2013). Surprisingly, conflicting results were found with CHIKV and DENV-2, where susceptibility to infection increased at lower rearing temperature (Westbrook et al., 2010; Evans et al., 2018). The same trend was observed for VEEV and RVFV in Ae. taeniorhynchus (Turell, 1993). Interestingly, larval rearing temperature did not show any effect on Culex mosquito susceptibility to RVFV or WNV (Brubaker and Turell, 1998; Dodson et al., 2012). These inconsistencies may reflect different interactions between virus and vectors and may suggest the presence of interfering factors sensitive to temperature.

Several life-history traits such as adult body size vary according to rearing temperature of immature stages. Large females absorb twice the volume of blood than smaller females (Briegel, 1990), thus potentially increasing viral load ingested by larger females. Ae. albopictus immature stages exposed to cooler temperatures grew into larger adults with increased CHIKV susceptibility (Westbrook et al., 2010). However, smallersized Ae. aegypti and Ae. albopictus were significantly more likely to become infected and to disseminate DENV-2 than larger individuals (Alto et al., 2008). Indeed, smaller mosquitoes might have higher ratios of infective dose/body weight and thus acquire higher concentrations of virus per body weight. Moreover, temperature can interfere with other stressors of the larval environment. At a low temperature, high larval density led to high infection rates of adults with SINV while the reverse was observed at high temperature (Muturi et al., 2012). In addition, cooler rearing temperature of immature stages resulted in enhanced trans-stadial transmission (from larvae to adult) of Saint Louis encephalitis virus (SLEV) in Aedes epactius (Hardy et al., 1980); the number of newly emerged adults harboring the virus was significantly higher in mosquitoes reared during immature stages at $18^{\circ} \mathrm{C}$ than those reared at $27^{\circ} \mathrm{C}$. Virus vertical transmission from females to their offspring is considered as a mechanism of persistence by which viruses are maintained in nature during unfavorable periods for horizontal transmission. Although debated, this phenomenon could have a significant impact on the subsistence and emergence of arboviruses outbreaks (Lequime and Lambrechts, 2014; Agarwal et al., 2017).

In nature, mosquitoes are submitted to daily and seasonal fluctuations of temperature. Understanding how temperature variations affect arbovirus transmission dynamics is critical to anticipate and limit the geographic and seasonal spread of MBDs. In that sense, mathematical models are pivotal tools in demonstrating the key role of temperature in VBD transmission (Huber et al., 2018; Tesla et al., 2018; Mordecai et al., 2019). More precisely, Mordecai et al. (2017) predicted in their mechanistic model that most tropical and subtropical regions are suitable for CHIKV, ZIKV, and DENV transmission during most months of the year while transmission in temperate regions is limited to only few months in summer, reducing the probability of major epidemics in those regions (Mordecai et al., 2017). In addition, thermodynamics models show that in tropical areas (mean temperature close to $29^{\circ} \mathrm{C}$ ), small diurnal temperature range (DTR), increases DENV transmission potential while under large DTR, it decreases. Whereas in cold temperate or extremely hot climates, DENV transmission potential increases as DTR increases (Lambrechts et al., 2011; Carrington et al., 2013; LiuHelmersson et al., 2014). Using climate change projections based on predicted temperature and DTR, mapped models showed an increasing trend over time for DENV epidemic potential in temperate regions (Liu-Helmersson et al., 2014).

The effect of climate change, especially global warming, on infectious diseases transmission has been the topic of intense debate. A large body of literature assumes that climate change will considerably modify VBDs epidemiological patterns (Reeves et al., 1994; Gould and Higgs, 2009; Mills et al., 2010; IPCC, 2014; Ryan et al., 2019). However, due to the complex interactions involved in transmission cycles and the unpredictable nature of both vectors and virus evolution, predicting the effects of climatic and environmental changes on VBDs emergence is extremely challenging (Tabachnick, 2010). Local adaptation to temperature of parasites and vectors may modulate the effects of climate change on VBDs dynamics and distribution (Sternberg and Thomas, 2014). Moreover, since mosquitoes are mobile and may move from habitats to stay in an optimal environment, they are not fully exposed to large temperature variations (Kramer, 2016). Microclimates encountered in urban areas (subways, houses...) have often higher and more stable temperatures than outdoor environments. This fosters vector survival and allows transmission cycle to persist despite adverse meteorological conditions (Haider et al., 2017). Thus, urbanization modifies 
climate within cities forming warmer spots; roads (with concrete and asphalt substrates) and air pollutants store the heat during daytime and release it at night, causing a rise in temperature compared to vegetated areas outside cities (Reisen, 2010). Obviously, other environmental factors including humidity, droughts, precipitation and flood act in concert with temperature to shape MBDs emergence and dynamics (Waldock et al., 2013b).

\section{DISCUSSION}

Typically, prevalent in the tropical belt, MBDs are now spreading, reaching even temperate regions. Over the last few decades, major pathogen-carrying vectors, like Ae. aegypti and Ae. albopictus, have significantly expanded their global distributions. MBDs burden is expected to continue to increase, especially under anticipated climate change scenarios. This situation raises many concerns about how temperature could change the current dynamics and expansion of MBDs. In this paper, we review current knowledge on the intricate interactions that reside between temperature, viruses and their vectors, in order to understand how collectively these effects may shape transmission dynamics. Temperature is one of the most significant abiotic factors affecting, in many ways, both the vectors and the pathogens they transmit. With great variance depending on vector species, populations and viral strains, temperature influences vector survival, vector population growth, distribution and genetic structure, host contact and feeding, virus susceptibility, EIP, virus structure and replication (Agarwal et al., 2017). While it is clear that factors such as high mosquito density, biting and survival rates promote transmission, it is more challenging to connect transmission to specific genetic (virus, mosquito holobiont...) and environmental variables (temperature, humidity, pollution...). Obviously, there are some combinations of factors that promote transmission while others hinder it; emergence happens when promoting factors outweigh hindering factors. There is an evident gap of information about how temperature influences virus evolution and phenotypes. In addition, deciphering how mosquito microbiota and immune functions implicated in viral transmission respond to temperature has a great importance.

In its overall effects, temperature may have a profound impact on natural ecosystems of rural and sylvatic cycles. New serotypes or currently unknown viruses could emerge from wildlife and affect humans following ecosystem alterations

\section{REFERENCES}

Adelman, Z. N., Anderson, M. A., Wiley, M. R., Murreddu, M. G., Samuel, G. H., Morazzani, E. M., et al. (2013). Cooler temperatures destabilize RNA interference and increase susceptibility of disease vector mosquitoes to viral infection. PLoS Negl. Trop. Dis. 7:e2239. doi: 10.1371/journal.pntd.000 2239

Agarwal, A., Parida, M., and Dash, P. K. (2017). Impact of transmission cycles and vector competence on global expansion and emergence of arboviruses. Rev. Med. Virol. doi: 10.1002/rmv.1941 [Epub ahead of print].

Alkan, C., Bichaud, L., de Lamballerie, X., Alten, B., Gould, E. A., and Charrel, R. N. (2013). Sandfly-borne phleboviruses of Eurasia and Africa: epidemiology, related to temperature changes; forest cycles are breeding grounds of unknown viruses representing a bottomless source of pathogens threatening human health (Fontenille and Powell, 2020). Neglected arboviruses are expected to become increasingly important, with temperature as a determinant factor of emergence (Lorenz et al., 2017). Beside temperature, many anthropophilic factors play crucial roles in the current success of MBDs (Kilpatrick and Randolph, 2012; Gould et al., 2017; Young, 2018). Human behavior, movement and land use in relation to climate change (population migration, water storage, unplanned urbanization. . .) are also subjects to explore. Notably, vector control strategies should include a temperature component in testing insecticide efficacy used in public health (Glunt et al., 2018).

Owing to the complex interactions between all partners of the vectorial system, more studies on the role of temperature on viral transmission are required. A better understanding of how transmission cycles interact with changing environments will help to better respond to future arbovirus outbreaks.

\section{AUTHOR CONTRIBUTIONS}

$\mathrm{RB}$ and $\mathrm{A}-\mathrm{BF}$ wrote the manuscript. Both authors have read and agreed to the published version of the manuscript.

\section{FUNDING}

This study was supported by the European Union's Horizon 2020 Research and Innovation Program under grant agreement no. 731060 (Infravec2, Research Infrastructures for the Control of Vector-Borne Diseases; http://infravec2.eu/), the Laboratoire d'Excellence "Integrative Biology of Emerging Infectious Diseases" (Grant No. ANR-10-LABX-62-IBEID), and the European Union's Horizon 2020 Research and Innovation Program under ZIKAlliance grant agreement no. 734548.

\section{ACKNOWLEDGMENTS}

We thank Marie Vazeille, Catherine Dauga, Adrien Blisnick, and Pei-Shi Yen for discussions, and Peter Sahlins for editing. We also thank Prof. François Rougeon for invaluable discussions on virus genetics.

genetic diversity, geographic range, control measures. Antiviral Res. 100, 54-74. doi: 10.1016/j.antiviral.2013.07.005

Alto, B. W., and Bettinardi, D. (2013). Temperature and dengue virus infection in mosquitoes: independent effects on the immature and adult stages. Am. J. Trop. Med. Hyg. 88, 497-505. doi: 10.4269/ajtmh.12-0421

Alto, B. W., Reiskind, M. H., and Lounibos, L. P. (2008). Size alters susceptibility of vectors to dengue virus infection and dissemination. Am. J. Trop. Med. Hyg. 79, 688-695. doi: 10.4269/ajtmh.2008.79.688

Andino, R., and Domingo, E. (2015). Viral quasispecies. Virology 479-480, 46-51. doi: 10.1016/j.virol.2015.03.022

Aranda, C., Martinez, M. J., Montalvo, T., Eritja, R., Navero-Castillejos, J., Herreros, E., et al. (2018). Arbovirus surveillance: first dengue virus detection 
in local Aedes albopictus mosquitoes in Europe, Catalonia, Spain, 2015. Euro Surveill. 23:1700837. doi: 10.2807/1560-7917.ES.2018.23.47.1700837

Bayoh, M. N., and Lindsay, S. W. (2004). Temperature-related duration of aquatic stages of the Afrotropical malaria vector mosquito Anopheles gambiae in the laboratory. Med. Vet. Entomol. 18, 174-179. doi: 10.1111/j.0269-283x.2004. 00495.x

Bhatt, S., Gething, P. W., Brady, O. J., Messina, J. P., Farlow, A. W., Moyes, C. L., et al. (2013). The global distribution and burden of dengue. Nature 496, 504-507. doi: 10.1038/nature 12060

Blair, C. D. (2011). Mosquito RNAi is the major innate immune pathway controlling Arbovirus infection and transmission. Future Microbiol. 6, 265-277. doi: $10.2217 / \mathrm{fmb} .11 .11$

Braack, L., Gouveia de Almeida, A. P., Cornel, A. J., Swanepoel, R., and de Jager, C. (2018). Mosquito-borne arboviruses of African origin: review of key viruses and vectors. Parasit. Vectors 11:29. doi: 10.1186/s13071-017-2559-9

Bradwell, K., Combe, M., Domingo-Calap, P., and Sanjuan, R. (2013). Correlation between mutation rate and genome size in riboviruses: mutation rate of bacteriophage Qbeta. Genetics 195, 243-251. doi: 10.1534/genetics.113.154963

Brady, O. J., Gething, P. W., Bhatt, S., Messina, J. P., Brownstein, J. S., Hoen, A. G., et al. (2012). Refining the global spatial limits of dengue virus transmission by evidence-based consensus. PLoS Negl. Trop. Dis. 6:e1760. doi: 10.1371/journal. pntd.0001760

Brady, O. J., Golding, N., Pigott, D. M., Kraemer, M. U., Messina, J. P., Reiner, R. C. Jr., et al. (2014). Global temperature constraints on Aedes aegypti and Ae. albopictus persistence and competence for dengue virus transmission. Parasit. Vectors 7:338. doi: 10.1186/1756-3305-7-338

Brady, O. J., and Hay, S. I. (2019). The first local cases of Zika virus in Europe. Lancet 394, 1991-1992. doi: 10.1016/s0140-6736(19)32790-4

Brady, O. J., Johansson, M. A., Guerra, C. A., Bhatt, S., Golding, N., Pigott, D. M., et al. (2013). Modelling adult Aedes aegypti and Aedes albopictus survival at different temperatures in laboratory and field settings. Parasit. Vectors 6:351. doi: 10.1186/1756-3305-6-351

Briegel, H. (1990). Fecundity, metabolism, and body size in Anopheles (Diptera: Culicidae), vectors of malaria. J. Med. Entomol. 27, 839-850. doi: 10.1093/ jmedent/27.5.839

Brubaker, J. F., and Turell, M. J. (1998). Effect of environmental temperature on the susceptibility of Culex pipiens (Diptera: Culicidae) to Rift Valley fever virus. J. Med. Entomol. 35, 918-921. doi: 10.1093/jmedent/35.6.918

Calba, C., Guerbois-Galla, M., Franke, F., Jeannin, C., Auzet-Caillaud, M., Grard, G., et al. (2017). Preliminary report of an autochthonous chikungunya outbreak in France, July to September 2017. Euro Surveill. 22:17-00647. doi: 10.2807/ 1560-7917.ES.2017.22.39.17-00647

Carrington, L. B., Armijos, M. V., Lambrechts, L., Barker, C. M., and Scott, T. W. (2013). Effects of fluctuating daily temperatures at critical thermal extremes on Aedes aegypti life-history traits. PLoS One 8:e58824. doi: 10.1371/journal.pone. 0058824

Chamberlain, R. W., and Sudia, W. D. (1955). The effects of temperature upon the extrinsic incubation of eastern equine encephalitis in mosquitoes. Am. J. Hyg. 62, 295-305. doi: 10.1093/oxfordjournals.aje.a119780

Chancey, C., Grinev, A., Volkova, E., and Rios, M. (2015). The global ecology and epidemiology of West Nile virus. Biomed Res. Int. 2015:376230. doi: 10.1155/ 2015/376230

Chastel, C. (2011). [Asymptomatic infections in man: a Trojan horse for the introduction and spread of mosquito-borne arboviruses in non-endemic areas?]. Bull. Soc. Pathol. Exot. 104, 213-219. doi: 10.1007/s13149-011-0165-1

Chepkorir, E., Lutomiah, J., Mutisya, J., Mulwa, F., Limbaso, K., Orindi, B., et al. (2014). Vector competence of Aedes aegypti populations from Kilifi and Nairobi for dengue 2 virus and the influence of temperature. Parasit. Vectors 7:435. doi: 10.1186/1756-3305-7-435

Christofferson, R. C., and Mores, C. N. (2016). Potential for extrinsic incubation temperature to alter interplay between transmission potential and mortality of dengue-infected Aedes aegypti. Environ. Health Insights 10, 119-123. doi: 10.4137/EHI.S38345

Ciota, A. T., Chin, P. A., Ehrbar, D. J., Micieli, M. V., Fonseca, D. M., and Kramer, L. D. (2018). Differential effects of temperature and mosquito genetics determine transmissibility of arboviruses by Aedes aegypti in Argentina. Am. J. Trop. Med. Hyg. 99, 417-424. doi: 10.4269/ajtmh.18-0097
Ciota, A. T., Jia, Y., Payne, A. F., Jerzak, G., Davis, L. J., Young, D. S., et al. (2009). Experimental passage of St. Louis encephalitis virus in vivo in mosquitoes and chickens reveals evolutionarily significant virus characteristics. PLoS One 4:e7876. doi: 10.1371/journal.pone.0007876

Ciota, A. T., and Kramer, L. D. (2010). Insights into Arbovirus evolution and adaptation from experimental studies. Viruses 2, 2594-2617. doi: 10.3390/ v2122594

Ciota, A. T., Matacchiero, A. C., Kilpatrick, A. M., and Kramer, L. D. (2014). The effect of temperature on life history traits of Culex mosquitoes. J. Med. Entomol. 51, 55-62. doi: 10.1603/ME13003

Coffey, L. L., Forrester, N., Tsetsarkin, K., Vasilakis, N., and Weaver, S. C. (2013). Factors shaping the adaptive landscape for arboviruses: implications for the emergence of disease. Future Microbiol. 8, 155-176. doi: 10.2217/fmb.12.139

Coffey, L. L., Vasilakis, N., Brault, A. C., Powers, A. M., Tripet, F., and Weaver, S. C. (2008). Arbovirus evolution in vivo is constrained by host alternation. Proc. Natl. Acad. Sci. U.S.A. 105, 6970-6975. doi: 10.1073/pnas.0712130105

da Cruz Ferreira, D. A., Degener, C. M., de Almeida Marques-Toledo, C., Bendati, M. M., Fetzer, L. O., Teixeira, C. P., et al. (2017). Meteorological variables and mosquito monitoring are good predictors for infestation trends of Aedes aegypti, the vector of dengue, chikungunya and Zika. Parasit. Vectors 10:78.

Davis, N. C. (1932). The effect of various temperatures in modifying the extrinsic incubation period of the yellow fever virus in Aëdes aegypti. Am. J. Epidemiol. 16, 163-176. doi: 10.1093/oxfordjournals.aje.a117853

Deardorff, E. R., Fitzpatrick, K. A., Jerzak, G. V., Shi, P. Y., Kramer, L. D., and Ebel, G. D. (2011). West Nile virus experimental evolution in vivo and the trade-off hypothesis. PLoS Pathog. 7:e1002335. doi: 10.1371/journal.ppat.1002335

Delatte, H., Gimonneau, G., Triboire, A., and Fontenille, D. (2009). Influence of temperature on immature development, survival, longevity, fecundity, and gonotrophic cycles of Aedes albopictus, vector of chikungunya and dengue in the Indian Ocean. J. Med. Entomol. 46, 33-41. doi: 10.1603/033.046.0105

Denlinger, D. L., and Armbruster, P. A. (2014). Mosquito diapause. Annu. Rev. Entomol. 59, 73-93. doi: 10.1146/annurev-ento-011613-162023

Dillon, R. J., and Dillon, V. M. (2004). The gut bacteria of insects: nonpathogenic interactions. Annu. Rev. Entomol. 49, 71-92.

Ding, F., Fu, J., Jiang, D., Hao, M., and Lin, G. (2018). Mapping the spatial distribution of Aedes aegypti and Aedes albopictus. Acta Trop. 178, 155-162. doi: 10.1016/j.actatropica.2017.11.020

Dodson, B. L., Kramer, L. D., and Rasgon, J. L. (2012). Effects of larval rearing temperature on immature development and West Nile virus vector competence of Culex tarsalis. Parasit. Vectors 5:199. doi: 10.1186/1756-3305-5-199

Dohm, D. J., O'Guinn, M. L., and Turell, M. J. (2002). Effect of environmental temperature on the ability of Culex pipiens (Diptera: Culicidae) to transmit West Nile virus. J. Med. Entomol. 39, 221-225. doi: 10.1603/0022-2585-39. 1.221

Domingo, E., Escarmís, C., Menéndez-Arias, L., Perales, C., Herrera, M., Novella, I. S., et al. (2008). CHAPTER 4 - viral quasispecies: dynamics, interactions, and pathogenesis. Orig. Evol. Viruses 4, 87-118. doi: 10.1016/b978-0-12-374153-0. 00004-7

Domingo, E., and Holland, J. J. (1997). RNA virus mutations and fitness for survival. Annu. Rev. Microbiol. 51, 151-178. doi: 10.1146/annurev.micro.51. 1.151

Domingo, E., and Perales, C. (2019). Viral quasispecies. PLoS Genet. 15:e1008271. doi: 10.1371/journal.pgen.1008271

Drake, J. W. (1999). The distribution of rates of spontaneous mutation over viruses, prokaryotes, and eukaryotes. Ann. N. Y. Acad. Sci. 870, 100-107. doi: 10.1111/ j.1749-6632.1999.tb08870.x

Drake, J. W., Charlesworth, B., Charlesworth, D., and Crow, J. F. (1998). Rates of spontaneous mutation. Genetics 148, 1667-1686.

Duffy, S., Shackelton, L. A., and Holmes, E. C. (2008). Rates of evolutionary change in viruses: patterns and determinants. Nat. Rev. Genet. 9, 267-276. doi: $10.1038 / \mathrm{nrg} 2323$

Duong, V., Lambrechts, L., Paul, R. E., Ly, S., Lay, R. S., Long, K. C., et al. (2015). Asymptomatic humans transmit dengue virus to mosquitoes. Proc. Natl. Acad. Sci. U.S.A. 112, 14688-14693. doi: 10.1073/pnas.1508114112

El Moustaid, F., and Johnson, L. R. (2019). Modeling temperature effects on population density of the dengue mosquito Aedes aegypti. Insects 10:393. doi: 10.3390/insects 10110393 
Endy, T. P., Anderson, K. B., Nisalak, A., Yoon, I. K., Green, S., Rothman, A. L., et al. (2011). Determinants of inapparent and symptomatic dengue infection in a prospective study of primary school children in Kamphaeng Phet, Thailand. PLoS Negl. Trop. Dis. 5:e975. doi: 10.1371/journal.pntd.0000975

Engel, P., and Moran, N. A. (2013). The gut microbiota of insects - diversity in structure and function. FEMS Microbiol. Rev. 37, 699-735. doi: 10.1111/15746976.12025

Evans, M. V., Shiau, J. C., Solano, N., Brindley, M. A., Drake, J. M., and Murdock, C. C. (2018). Carry-over effects of urban larval environments on the transmission potential of dengue-2 virus. Parasit. Vectors 11:426.

Ezeakacha, N. F., and Yee, D. A. (2019). The role of temperature in affecting carryover effects and larval competition in the globally invasive mosquito Aedes albopictus. Parasit. Vectors 12:123.

Farjana, T., and Tuno, N. (2013). Multiple blood feeding and host-seeking behavior in Aedes aegypti and Aedes albopictus (Diptera: Culicidae). J. Med. Entomol. 50, 838-846. doi: 10.1603/me12146

Fields, P. A., Dong, Y., Meng, X., and Somero, G. N. (2015). Adaptations of protein structure and function to temperature: there is more than one way to 'skin a cat'. J. Exp. Biol. 218(Pt 12), 1801-1811. doi: 10.1242/jeb.114298

Fontenille, D., and Powell, J. R. (2020). From anonymous to public enemy: how does a mosquito become a feared Arbovirus vector? Pathogens 9:265. doi: 10.3390/pathogens 9040265

Forrester, N. L., Coffey, L. L., and Weaver, S. C. (2014). Arboviral bottlenecks and challenges to maintaining diversity and fitness during mosquito transmission. Viruses 6, 3991-4004. doi: 10.3390/v6103991

Fragkoudis, R., Attarzadeh-Yazdi, G., Nash, A. A., Fazakerley, J. K., and Kohl, A. (2009). Advances in dissecting mosquito innate immune responses to Arbovirus infection. J. Gen. Virol. 90(Pt 9), 2061-2072. doi: 10.1099/vir.0.013201-0

Franz, A. W., Kantor, A. M., Passarelli, A. L., and Clem, R. J. (2015). Tissue barriers to Arbovirus infection in mosquitoes. Viruses 7, 3741-3767. doi: 10.3390/ v7072795

Gale, P. (2019). Towards a thermodynamic mechanistic model for the effect of temperature on arthropod vector competence for transmission of arboviruses. Microb. Risk Anal. 12, 27-43. doi: 10.1016/j.mran.2019.03.001

Gjenero-Margan, I., Aleraj, B., Krajcar, D., Lesnikar, V., Klobucar, A., Pem-Novosel, I., et al. (2011). Autochthonous dengue fever in Croatia, August-September 2010. Euro Surveill. 16:19805.

Gloria-Soria, A., Armstrong, P. M., Powell, J. R., and Turner, P. E. (2017). Infection rate of Aedes aegypti mosquitoes with dengue virus depends on the interaction between temperature and mosquito genotype. Proc. Biol. Sci. 284:20171506. doi: $10.1098 /$ rspb.2017.1506

Glunt, K. D., Oliver, S. V., Hunt, R. H., and Paaijmans, K. P. (2018). The impact of temperature on insecticide toxicity against the malaria vectors Anopheles arabiensis and Anopheles funestus. Malar. J. 17:131.

Gonçalves Ferreira, P., Tesla, B., Alves Horácio, E., Alves Nahum, L., Brindley, M., Antônio de Oliveira Mendes, T., et al. (2020). Temperature dramatically shapes mosquito gene expression with consequences for mosquito-Zika virus interactions. Front. Microbiol. 11:901. doi: 10.3389/fmicb.2020.00901

Gould, E., Pettersson, J., Higgs, S., Charrel, R., and de Lamballerie, X. (2017). Emerging arboviruses: why today? One Health 4, 1-13. doi: 10.1016/j.onehlt. 2017.06.001

Gould, E. A., and Higgs, S. (2009). Impact of climate change and other factors on emerging Arbovirus diseases. Trans. R. Soc. Trop. Med. Hyg. 103, 109-121. doi: 10.1016/j.trstmh.2008.07.025

Grandadam, M., Caro, V., Plumet, S., Thiberge, J. M., Souares, Y., Failloux, A. B., et al. (2011). Chikungunya virus, southeastern France. Emerg. Infect. Dis. 17, 910-913.

Grech, M. G., Sartor, P. D., Almiron, W. R., and Luduena-Almeida, F. F. (2015). Effect of temperature on life history traits during immature development of Aedes aegypti and Culex quinquefasciatus (Diptera: Culicidae) from Cordoba city, Argentina. Acta Trop. 146, 1-6. doi: 10.1016/j.actatropica.2015. 02.010

Grubaugh, N. D., Weger-Lucarelli, J., Murrieta, R. A., Fauver, J. R., Garcia-Luna, S. M., Prasad, A. N., et al. (2016). Genetic drift during systemic Arbovirus infection of mosquito vectors leads to decreased relative fitness during host switching. Cell Host Microbe 19, 481-492.

Gubler, D. J. (1996). The global resurgence of Arboviral diseases. Trans. R. Soc. Trop. Med. Hyg. 90, 449-451. doi: 10.1016/s0035-9203(96)90286-2
Gubler, D. J. (2002a). Epidemic dengue/dengue hemorrhagic fever as a public health, social and economic problem in the 21st century. Trends Microbiol. 10, 100-103. doi: 10.1016/s0966-842x(01)02288-0

Gubler, D. J. (2002b). The global emergence/resurgence of Arboviral diseases as public health problems. Arch. Med. Res. 33, 330-342. doi: 10.1016/s01884409(02)00378-8

Gubler, D. J., Vasilakis, N., and Musso, D. (2017). History and emergence of Zika virus. J. Infect. Dis. 216(Suppl._10), S860-S867.

Guegan, M., Minard, G., Tran, F. H., Tran Van, V., Dubost, A., and Valiente Moro, C. (2018a). Short-term impacts of anthropogenic stressors on Aedes albopictus mosquito vector microbiota. FEMS Microbiol. Ecol. 94:fiy188.

Guegan, M., Zouache, K., Demichel, C., Minard, G., Tran Van, V., Potier, P., et al. (2018b). The mosquito holobiont: fresh insight into mosquito-microbiota interactions. Microbiome 6:49.

Haider, N., Kirkeby, C., Kristensen, B., Kjaer, L. J., Sorensen, J. H., and Bodker, R. (2017). Microclimatic temperatures increase the potential for vector-borne disease transmission in the Scandinavian climate. Sci. Rep. 7:8175.

Hanson, S. M., and Craig, G. B. Jr. (1994). Cold acclimation, diapause, and geographic origin affect cold hardiness in eggs of Aedes albopictus (Diptera: Culicidae). J. Med. Entomol. 31, 192-201. doi: 10.1093/jmedent/31.2.192

Hanson, S. M., and Craig, G. B. Jr. (1995). Relationship between cold hardiness and supercooling point in Aedes albopictus eggs. J. Am. Mosq. Control Assoc. $11,35-38$.

Hardy, J. L., Houk, E. J., Kramer, L. D., and Reeves, W. C. (1983). Intrinsic factors affecting vector competence of mosquitoes for arboviruses. Annu. Rev. Entomol. 28, 229-262. doi: 10.1146/annurev.en.28.010183.001305

Hardy, J. L., Rosen, L., Kramer, L. D., Presser, S. B., Shroyer, D. A., and Turell, M. J. (1980). Effect of rearing temperature on transovarial transmission of St. Louis encephalitis virus in mosquitoes. Am. J. Trop. Med. Hyg. 29, 963-968. doi: 10.4269/ajtmh.1980.29.963

Hawley, W. A., Pumpuni, C. B., Brady, R. H., and Craig, G. B. Jr. (1989). Overwintering survival of Aedes albopictus (Diptera: Culicidae) eggs in Indiana. J. Med. Entomol. 26, 122-129. doi: 10.1093/jmedent/26.2.122

Hegde, S., Rasgon, J. L., and Hughes, G. L. (2015). The microbiome modulates Arbovirus transmission in mosquitoes. Curr. Opin. Virol. 15, 97-102. doi: 10.1016/j.coviro.2015.08.011

Heitmann, A., Jansen, S., Luhken, R., Helms, M., Pluskota, B., Becker, N., et al. (2018). Experimental risk assessment for chikungunya virus transmission based on vector competence, distribution and temperature suitability in Europe, 2018. Euro Surveill. 23:1800033.

Holmes, E. C. (2003). Error thresholds and the constraints to RNA virus evolution. Trends Microbiol. 11, 543-546. doi: 10.1016/j.tim.2003.10.006

Honorio, N. A., Nogueira, R. M., Codeco, C. T., Carvalho, M. S., Cruz, O. G., Magalhaes Mde, A., et al. (2009). Spatial evaluation and modeling of dengue seroprevalence and vector density in Rio de Janeiro, Brazil. PLoS Negl. Trop. Dis. 3:e545. doi: 10.1371/journal.pntd.0000545

Houe, V., Bonizzoni, M., and Failloux, A. B. (2019). Endogenous non-retroviral elements in genomes of Aedes mosquitoes and vector competence. Emerg. Microbes Infect. 8, 542-555. doi: 10.1080/22221751.2019.1599302

Huber, J. H., Childs, M. L., Caldwell, J. M., and Mordecai, E. A. (2018). Seasonal temperature variation influences climate suitability for dengue, chikungunya, and Zika transmission. PLoS Negl. Trop. Dis. 12:e0006451. doi: 10.1371/journal. pntd.0006451

Impoinvil, D. E., Cardenas, G. A., Gihture, J. I., Mbogo, C. M., and Beier, J. C. (2007). Constant temperature and time period effects on Anopheles gambiae egg hatching. J. Am. Mosq. Control Assoc. 23, 124-130. doi: 10.2987/8756$971 \times(2007) 23[124:$ ctatpe $] 2.0 . c 0 ; 2$

IPCC (2014). Climate Change 2014: Synthesis Report. Contribution of Working Groups I, II and III to the Fifth Assessment Report of the Intergovernmental Panel on Climate Change. Geneva: IPCC.

Jansen, S., Heitmann, A., Luhken, R., Jost, H., Helms, M., Vapalahti, O., et al. (2018). Experimental transmission of Zika virus by Aedes japonicus japonicus from southwestern Germany. Emerg. Microbes Infect. 7:192.

Jenkins, G. M., Rambaut, A., Pybus, O. G., and Holmes, E. C. (2002). Rates of molecular evolution in RNA viruses: a quantitative phylogenetic analysis. J. Mol. Evol. 54, 156-165. doi: 10.1007/s00239-001-0064-3

Jones, K. E., Patel, N. G., Levy, M. A., Storeygard, A., Balk, D., Gittleman, J. L., et al. (2008). Global trends in emerging infectious diseases. Nature 451, 990-993. 
Jupatanakul, N., Sim, S., and Dimopoulos, G. (2014). The insect microbiome modulates vector competence for arboviruses. Viruses 6, 4294-4313. doi: 10. 3390/v6114294

Kashiwagi, A., Sugawara, R., Sano Tsushima, F., Kumagai, T., and Yomo, T. (2014). Contribution of silent mutations to thermal adaptation of RNA bacteriophage Qbeta. J. Virol. 88, 11459-11468. doi: 10.1128/jvi.01127-14

Kazimirova, M., Thangamani, S., Bartikova, P., Hermance, M., Holikova, V., Stibraniova, I., et al. (2017). Tick-borne viruses and biological processes at the tick-host-virus interface. Front. Cell. Infect. Microbiol. 7:339. doi: 10.3389/ fcimb.2017.00339

Kikuchi, Y., Tada, A., Musolin, D. L., Hari, N., Hosokawa, T., Fujisaki, K., et al. (2016). Collapse of insect gut symbiosis under simulated climate change. mBio 7:e01578-16.

Kilpatrick, A. M., Meola, M. A., Moudy, R. M., and Kramer, L. D. (2008). Temperature, viral genetics, and the transmission of West Nile virus by Culex pipiens mosquitoes. PLoS Pathog. 4:e1000092. doi: 10.1371/journal.ppat. 1000092

Kilpatrick, A. M., and Randolph, S. E. (2012). Drivers, dynamics, and control of emerging vector-borne zoonotic diseases. Lancet 380, 1946-1955. doi: 10.1016/ s0140-6736(12)61151-9

Kinney, R. M., Huang, C. Y., Whiteman, M. C., Bowen, R. A., Langevin, S. A., Miller, B. R., et al. (2006). Avian virulence and thermostable replication of the North American strain of West Nile virus. J. Gen. Virol. 87(Pt 12), 3611-3622. doi: 10.1099/vir.0.82299-0

Kraemer, M. U., Sinka, M. E., Duda, K. A., Mylne, A. Q., Shearer, F. M., Barker, C. M., et al. (2015). The global distribution of the Arbovirus vectors Aedes aegypti and Ae. albopictus. eLife 4:e08347.

Kramer, L. D. (2016). Complexity of virus-vector interactions. Curr. Opin. Virol. 21, 81-86. doi: 10.1016/j.coviro.2016.08.008

Kramer, L. D., and Ciota, A. T. (2015). Dissecting vectorial capacity for mosquitoborne viruses. Curr. Opin. Virol. 15, 112-118. doi: 10.1016/j.coviro.2015. 10.003

Kramer, L. D., Hardy, J. L., and Presser, S. B. (1983). Effect of temperature of extrinsic incubation on the vector competence of Culex tarsalis for western equine encephalomyelitis virus. Am. J. Trop. Med. Hyg. 32, 1130-1139. doi: 10.4269/ajtmh.1983.32.1130

Krokan, H. E., Drablos, F., and Slupphaug, G. (2002). Uracil in DNA-occurrence, consequences and repair. Oncogene 21, 8935-8948. doi: 10.1038/sj.onc.1205996

Kumar, A., Srivastava, P., Sirisena, P., Dubey, S. K., Kumar, R., Shrinet, J., et al. (2018). Mosquito innate immunity. Insects 9:95. doi: 10.3390/insects 9030095

Lambrechts, L., Chevillon, C., Albright, R. G., Thaisomboonsuk, B., Richardson, J. H., Jarman, R. G., et al. (2009). Genetic specificity and potential for local adaptation between dengue viruses and mosquito vectors. BMC Evol. Biol. 9:160. doi: 10.1186/1471-2148-9-160

Lambrechts, L., Paaijmans, K. P., Fansiri, T., Carrington, L. B., Kramer, L. D., Thomas, M. B., et al. (2011). Impact of daily temperature fluctuations on dengue virus transmission by Aedes aegypti. Proc. Natl. Acad. Sci. U.S.A. 108, 7460-7465. doi: 10.1073/pnas.1101377108

Lauring, A. S., Frydman, J., and Andino, R. (2013). The role of mutational robustness in RNA virus evolution. Nat. Rev. Microbiol. 11, 327-336. doi: 10.1038/nrmicro3003

Lazcano, A., Guerrero, R., Margulis, L., and Oro, J. (1988). The evolutionary transition from RNA to DNA in early cells. J. Mol. Evol. 27, 283-290. doi: $10.1007 / \mathrm{bf} 02101189$

Lequime, S., and Lambrechts, L. (2014). Vertical transmission of arboviruses in mosquitoes: a historical perspective. Infect. Genet. Evol. 28, 681-690. doi: 10.1016/j.meegid.2014.07.025

Lindahl, T. (1996). The Croonian Lecture, 1996: endogenous damage to DNA. Philos. Trans. R. Soc. Lond. B Biol. Sci. 351, 1529-1538. doi: 10.1098/rstb.1996. 0139

Liu, Z., Zhang, Z., Lai, Z., Zhou, T., Jia, Z., Gu, J., et al. (2017). Temperature increase enhances Aedes albopictus competence to transmit dengue virus. Front. Microbiol. 8:2337. doi: 10.3389/fmicb.2017.02337

Liu-Helmersson, J., Stenlund, H., Wilder-Smith, A., and Rocklov, J. (2014). Vectorial capacity of Aedes aegypti: effects of temperature and implications for global dengue epidemic potential. PLoS One 9:e89783. doi: 10.1371/journal. pone. 0089783
Loetti, V., Schweigmann, N. J., and Burroni, N. E. (2011). Temperature effects on the immature development time of Culex eduardoi Casal \& Garcia (Diptera: Culicidae). Neotrop. Entomol. 40, 138-142. doi: 10.1590/s1519$566 \times 2011000100021$

Lokmer, A., and Mathias Wegner, K. (2015). Hemolymph microbiome of Pacific oysters in response to temperature, temperature stress and infection. ISME J. 9, 670-682. doi: 10.1038/ismej.2014.160

Lorenz, C., Azevedo, T. S., Virginio, F., Aguiar, B. S., Chiaravalloti-Neto, F., and Suesdek, L. (2017). Impact of environmental factors on neglected emerging Arboviral diseases. PLoS Negl. Trop. Dis. 11:e0005959. doi: 10.1371/journal. pntd.0005959

Macdonald, G. (1957). The Epidemiology and Control of Malaria. Oxford: Oxford University Press.

Malik Peiris, J. S., and Parrish, C. R. (2011). Emerging viruses. Curr. Opin. Virol. 1, 617-619.

Mayer, S. V., Tesh, R. B., and Vasilakis, N. (2017). The emergence of arthropodborne viral diseases: a global prospective on dengue, chikungunya and Zika fevers. Acta Trop. 166, 155-163. doi: 10.1016/j.actatropica.2016.11.020

Mbaika, S., Lutomiah, J., Chepkorir, E., Mulwa, F., Khayeka-Wandabwa, C., Tigoi, C., et al. (2016). Vector competence of Aedes aegypti in transmitting Chikungunya virus: effects and implications of extrinsic incubation temperature on dissemination and infection rates. Virol. J. 13:114.

Messina, J. P., Brady, O. J., Scott, T. W., Zou, C., Pigott, D. M., Duda, K. A., et al. (2014). Global spread of dengue virus types: mapping the 70 year history. Trends Microbiol. 22, 138-146. doi: 10.1016/j.tim.2013.12.011

Mills, J. N., Gage, K. L., and Khan, A. S. (2010). Potential influence of climate change on vector-borne and zoonotic diseases: a review and proposed research plan. Environ. Health Perspect. 118, 1507-1514. doi: 10.1289/ehp.0901389

Moghadam, N. N., Thorshauge, P. M., Kristensen, T. N., de Jonge, N., Bahrndorff, S., Kjeldal, H., et al. (2018). Strong responses of Drosophila melanogaster microbiota to developmental temperature. Fly 12, 1-12. doi: 10.1080/19336934. 2017.1394558

Mohammed, A., and Chadee, D. D. (2011). Effects of different temperature regimens on the development of Aedes aegypti (L.) (Diptera: Culicidae) mosquitoes. Acta Trop. 119, 38-43. doi: 10.1016/j.actatropica.2011.04.004

Monath, T. P., and Vasconcelos, P. F. (2015). Yellow fever. J. Clin. Virol. 64, $160-173$.

Mordecai, E. A., Caldwell, J. M., Grossman, M. K., Lippi, C. A., Johnson, L. R., Neira, M., et al. (2019). Thermal biology of mosquito-borne disease. Ecol. Lett. $22,1690-1708$.

Mordecai, E. A., Cohen, J. M., Evans, M. V., Gudapati, P., Johnson, L. R., Lippi, C. A., et al. (2017). Detecting the impact of temperature on transmission of Zika, dengue, and chikungunya using mechanistic models. PLoS Negl. Trop. Dis. 11:e0005568. doi: 10.1371/journal.pntd.0005568

Morris, M., and Rogers, S. M. (2014). Integrating phenotypic plasticity within an ecological genomics framework: recent insights from the genomics, evolution, ecology, and fitness of plasticity. Adv. Exp. Med. Biol. 781, 73-105. doi: 10.1007/ 978-94-007-7347-9_5

Moya, A., Elena, S. F., Bracho, A., Miralles, R., and Barrio, E. (2000). The evolution of RNA viruses: a population genetics view. Proc. Natl. Acad. Sci. U.S.A. 97, 6967-6973.

Murdock, C. C., Paaijmans, K. P., Cox-Foster, D., Read, A. F., and Thomas, M. B. (2012). Rethinking vector immunology: the role of environmental temperature in shaping resistance. Nat. Rev. Microbiol. 10, 869-876. doi: 10. 1038/nrmicro2900

Muturi, E. J., Blackshear, M. Jr., and Montgomery, A. (2012). Temperature and density-dependent effects of larval environment on Aedes aegypti competence for an alphavirus. J. Vector Ecol. 37, 154-161. doi: 10.1111/j.1948-7134.2012. 00212.x

Muturi, E. J., Kim, C. H., Alto, B. W., Berenbaum, M. R., and Schuler, M. A. (2011). Larval environmental stress alters Aedes aegypti competence for Sindbis virus. Trop. Med. Int. Health 16, 955-964. doi: 10.1111/j.1365-3156.2011.02796.x

Nachman, M. W., and Crowell, S. L. (2000). Estimate of the mutation rate per nucleotide in humans. Genetics 156, 297-304.

Nawrocki, S. J., and Hawley, W. A. (1987). Estimation of the northern limits of distribution of Aedes albopictus in North America. J. Am. Mosq. Control Assoc. $3,314-317$. 
Novakova, E., Woodhams, D. C., Rodriguez-Ruano, S. M., Brucker, R. M., Leff, J. W., Maharaj, A., et al. (2017). Mosquito microbiome dynamics, a background for prevalence and seasonality of west Nile virus. Front. Microbiol. 8:526. doi: 10.3389/fmicb.2017.00526

Novella, I. S., Hershey, C. L., Escarmis, C., Domingo, E., and Holland, J. J. (1999). Lack of evolutionary stasis during alternating replication of an Arbovirus in insect and mammalian cells. J. Mol. Biol. 287, 459-465. doi: 10.1006/jmbi.1999. 2635

Ong, A., Sandar, M., Chen, M. I., and Sin, L. Y. (2007). Fatal dengue hemorrhagic fever in adults during a dengue epidemic in Singapore. Int. J. Infect. Dis. 11, 263-267. doi: 10.1016/j.ijid.2006.02.012

Pain, R. H. (1987). Temperature and macromolecular structure and function. Symp. Soc. Exp. Biol. 41, 21-33.

Pezzi, L., Reusken, C. B., Weaver, S. C., Drexler, J. F., Busch, M., LaBeaud, A. D., et al. (2019). GloPID-R report on Chikungunya, O'nyong-nyong and Mayaro virus, part I: biological diagnostics. Antiviral Res. 166, 66-81. doi: 10.1016/j. antiviral.2019.03.009

Pigllucci, M. (1996). How organisms respond to environmental changes: from phenotypes to molecules (and vice versa). Trends Ecol. Evol. 11, 168-173. doi: 10.1016/0169-5347(96)10008-2

Prado, S. S., Hung, K. Y., Daugherty, M. P., and Almeida, R. P. (2010). Indirect effects of temperature on stink bug fitness, via maintenance of gut-associated symbionts. Appl. Environ. Microbiol. 76, 1261-1266. doi: 10.1128/aem. 02034-09

Ramirez, J. L., Souza-Neto, J., Torres Cosme, R., Rovira, J., Ortiz, A., Pascale, J. M., et al. (2012). Reciprocal tripartite interactions between the Aedes aegypti midgut microbiota, innate immune system and dengue virus influences vector competence. PLoS Negl. Trop. Dis. 6:e1561. doi: 10.1371/journal.pntd.0001561

Reeves, W. C., Hardy, J. L., Reisen, W. K., and Milby, M. M. (1994). Potential effect of global warming on mosquito-borne arboviruses. J. Med. Entomol. 31, 323-332. doi: 10.1093/jmedent/31.3.323

Reinhold, J. M., Lazzari, C. R., and Lahondere, C. (2018). Effects of the environmental temperature on Aedes aegypti and Aedes albopictus mosquitoes: a review. Insects 9:158. doi: 10.3390/insects 9040158

Reisen, W. K. (2010). Landscape epidemiology of vector-borne diseases. Annu. Rev. Entomol. 55, 461-483. doi: 10.1146/annurev-ento-112408-085419

Rey, F. A. (2013). Dengue virus: two hosts, two structures. Nature 497, 443-444. doi: 10.1038/497443a

Rezelj, V. V., Levi, L. I., and Vignuzzi, M. (2018). The defective component of viral populations. Curr. Opin. Virol. 33, 74-80. doi: 10.1016/j.coviro.2018.07.014

Rezza, G. (2018). Chikungunya is back in Italy: 2007-2017. J. Travel Med. 25:tay004.

Richards, S. L., Mores, C. N., Lord, C. C., and Tabachnick, W. J. (2007). Impact of extrinsic incubation temperature and virus exposure on vector competence of Culex pipiens quinquefasciatus Say (Diptera: Culicidae) for West Nile virus. Vector Borne Zoonotic Dis. 7, 629-636. doi: 10.1089/vbz.2007.0101

Rowley, W. A., and Graham, C. L. (1968). The effect of temperature and relative humidity on the flight performance of female Aedes aegypti. J. Insect Physiol. 14, 1251-1257. doi: 10.1016/0022-1910(68)90018-8

Ruckert, C., and Ebel, G. D. (2018). How do virus-mosquito interactions lead to viral emergence? Trends Parasitol. 34, 310-321. doi: 10.1016/j.pt.2017.12.004

Ryan, S. J., Carlson, C. J., Mordecai, E. A., and Johnson, L. R. (2019). Global expansion and redistribution of Aedes-borne virus transmission risk with climate change. PLoS Negl. Trop. Dis. 13:e0007213. doi: 10.1371/journal.pntd. 0007213

Sabatini, A., Raineri, V., Trovato, G., and Coluzzi, M. (1990). [Aedes albopictus in Italy and possible diffusion of the species into the Mediterranean area]. Parassitologia 32, 301-304.

Samuel, G. H., Adelman, Z. N., and Myles, K. M. (2016). Temperature-dependent effects on the replication and transmission of arthropod-borne viruses in their insect hosts. Curr. Opin. Insect Sci. 16, 108-113. doi: 10.1016/j.cois.2016.06.005

Samy, A. M., Elaagip, A. H., Kenawy, M. A., Ayres, C. F., Peterson, A. T., and Soliman, D. E. (2016). Climate change influences on the global potential distribution of the mosquito Culex quinquefasciatus, vector of West Nile virus and lymphatic filariasis. PLoS One 11:e0163863. doi: 10.1371/journal.pone. 0163863

Sanjuan, R., and Domingo-Calap, P. (2016). Mechanisms of viral mutation. Cell. Mol. Life Sci. 73, 4433-4448. doi: 10.1007/s00018-016-2299-6
Sanjuan, R., Nebot, M. R., Chirico, N., Mansky, L. M., and Belshaw, R. (2010). Viral mutation rates. J. Virol. 84, 9733-9748.

Schuffenecker, I., Iteman, I., Michault, A., Murri, S., Frangeul, L., Vaney, M. C., et al. (2006). Genome microevolution of chikungunya viruses causing the Indian Ocean outbreak. PLoS Med. 3:e263. doi: 10.1371/journal.pmed.003 0263

Scott, T. W., Amerasinghe, P. H., Morrison, A. C., Lorenz, L. H., Clark, G. G., Strickman, D., et al. (2000). Longitudinal studies of Aedes aegypti (Diptera: Culicidae) in Thailand and Puerto Rico: blood feeding frequency. J. Med. Entomol. 37, 89-101. doi: 10.1603/0022-2585-37.1.89

Sejvar, J. J. (2003). West Nile virus: an historical overview. Ochsner J. 5, 6-10.

Shelton, R. M. (1973). The effect of temperatures on development of eight mosquito species. Mosq. News 33, 1-12.

Shepard, D. S., Undurraga, E. A., Halasa, Y. A., and Stanaway, J. D. (2016). The global economic burden of dengue: a systematic analysis. Lancet Infect. Dis. 16, 935-941. doi: 10.1016/s1473-3099(16)00146-8

Sicard, M., Bonneau, M., and Weill, M. (2019). Wolbachia prevalence, diversity, and ability to induce cytoplasmic incompatibility in mosquitoes. Curr. Opin. Insect Sci. 34, 12-20. doi: 10.1016/j.cois.2019.02.005

Sick, F., Beer, M., Kampen, H., and Wernike, K. C. (2019). Culicoides biting midges-underestimated vectors for arboviruses of public health and veterinary importance. Viruses 11:376. doi: 10.3390/v11040376

Silva, L. A., and Dermody, T. S. (2017). Chikungunya virus: epidemiology, replication, disease mechanisms, and prospective intervention strategies. J. Clin. Invest. 127, 737-749. doi: 10.1172/jci84417

Sim, S., Aw, P. P., Wilm, A., Teoh, G., Hue, K. D., Nguyen, N. M., et al. (2015). Tracking dengue virus intra-host genetic diversity during human-to-mosquito transmission. PLoS Negl. Trop. Dis. 9:e0004052. doi: 10.1371/journal.pntd. 0004052

Simpson, D. I. (1964). Zika virus infection in man. Trans. R. Soc. Trop. Med. Hyg. $58,335-338$.

Steinhauer, D. A., Domingo, E., and Holland, J. J. (1992). Lack of evidence for proofreading mechanisms associated with an RNA virus polymerase. Gene 122, 281-288. doi: 10.1016/0378-1119(92)90216-c

Sternberg, E. D., and Thomas, M. B. (2014). Local adaptation to temperature and the implications for vector-borne diseases. Trends Parasitol. 30, 115-122. doi: 10.1016/j.pt.2013.12.010

Strand, M. R. (2018). Composition and functional roles of the gut microbiota in mosquitoes. Curr. Opin. Insect Sci. 28, 59-65. doi: 10.1016/j.cois.2018. 05.008

Tabachnick, W. J. (2010). Challenges in predicting climate and environmental effects on vector-borne disease episystems in a changing world. J. Exp. Biol. 213, 946-954. doi: 10.1242/jeb.037564

Tesla, B., Demakovsky, L. R., Mordecai, E. A., Ryan, S. J., Bonds, M. H., Ngonghala, C. N., et al. (2018). Temperature drives Zika virus transmission: evidence from empirical and mathematical models. Proc. Biol. Sci. 285:20180795. doi: 10.1098/ rspb.2018.0795

Thomas, S. M., Obermayr, U., Fischer, D., Kreyling, J., and Beierkuhnlein, C. (2012). Low-temperature threshold for egg survival of a post-diapause and nondiapause European aedine strain, Aedes albopictus (Diptera: Culicidae). Parasit. Vectors 5:100.

Tsetsarkin, K. A., Vanlandingham, D. L., McGee, C. E., and Higgs, S. (2007). A single mutation in chikungunya virus affects vector specificity and epidemic potential. PLoS Pathog. 3:e201. doi: 10.1371/journal.ppat.0030201

Tun-Lin, W., Burkot, T. R., and Kay, B. H. (2000). Effects of temperature and larval diet on development rates and survival of the dengue vector Aedes aegypti in north Queensland, Australia. Med. Vet. Entomol. 14, 31-37. doi: 10.1046/j. 1365-2915.2000.00207.x

Turell, M. J. (1993). Effect of environmental temperature on the vector competence of Aedes taeniorhynchus for Rift Valley fever and Venezuelan equine encephalitis viruses. Am. J. Trop. Med. Hyg. 49, 672-676. doi: 10.4269/ ajtmh.1993.49.672

Valentine, M. J., Murdock, C. C., and Kelly, P. J. (2019). Sylvatic cycles of arboviruses in non-human primates. Parasit. Vectors 12:463.

Vancini, R., Wang, G., Ferreira, D., Hernandez, R., and Brown, D. T. (2013). Alphavirus genome delivery occurs directly at the plasma membrane in a timeand temperature-dependent process. J. Virol. 87, 4352-4359. doi: 10.1128/jvi. 03412-12 
Vasconcelos, P. F., and Monath, T. P. (2016). Yellow fever remains a potential threat to public health. Vector Borne Zoonotic Dis. 16, 566-567. doi: 10.1089/ vbz.2016.2031

Vasilakis, N., Deardorff, E. R., Kenney, J. L., Rossi, S. L., Hanley, K. A., and Weaver, S. C. (2009). Mosquitoes put the brake on Arbovirus evolution: experimental evolution reveals slower mutation accumulation in mosquito than vertebrate cells. PLoS Pathog. 5:e1000467. doi: 10.1371/journal.ppat.1000467

Vazeille, M., Moutailler, S., Coudrier, D., Rousseaux, C., Khun, H., Huerre, M., et al. (2007). Two Chikungunya isolates from the outbreak of La Reunion (Indian Ocean) exhibit different patterns of infection in the mosquito, Aedes albopictus. PLoS One 2:e1168. doi: 10.1371/journal.pone.0001168

Vogels, C. B., Fros, J. J., Goertz, G. P., Pijlman, G. P., and Koenraadt, C. J. (2016). Vector competence of northern European Culex pipiens biotypes and hybrids for West Nile virus is differentially affected by temperature. Parasit. Vectors 9:393.

Waldock, J., Chandra, N. L., Lelieveld, J., Proestos, Y., Michael, E., Christophides, G., et al. (2013a). The role of environmental variables on Aedes albopictus biology and chikungunya epidemiology. Pathog. Glob. Health 107, 224-241.

Waldock, J., Parham, P. E., Lelieveld, J., and Christophides, G. K. (2013b). Climate and human health: the impact of climate change on vector-borne diseases, Paphos, Cyprus (17-19 October 2012). Pathog. Glob. Health 107, 387-392. doi: 10.1179/2047772413z.000000000161

Weaver, S. C., and Reisen, W. K. (2010). Present and future Arboviral threats. Antiviral Res. 85, 328-345. doi: 10.1016/j.antiviral.2009.10.008

Westbrook, C. J., Reiskind, M. H., Pesko, K. N., Greene, K. E., and Lounibos, L. P. (2010). Larval environmental temperature and the susceptibility of Aedes albopictus Skuse (Diptera: Culicidae) to Chikungunya virus. Vector Borne Zoonotic Dis. 10, 241-247.

Wimalasiri-Yapa, B., Stassen, L., Hu, W., Yakob, L., McGraw, E. A., Pyke, A. T., et al. (2019). Chikungunya virus transmission at low temperature by Aedes albopictus mosquitoes. Pathogens 8:149. doi: 10.3390/pathogens8030149

Winokur, O. C., Main, B. J., Nicholson, J., and Barker, C. M. (2020). Impact of temperature on the extrinsic incubation period of Zika virus in Aedes aegypti. PLoS Negl. Trop. Dis. 14:e0008047. doi: 10.1371/journal.pntd.0008047

Xiao, F. Z., Zhang, Y., Deng, Y. Q., He, S., Xie, H. G., Zhou, X. N., et al. (2014). The effect of temperature on the extrinsic incubation period and infection rate of dengue virus serotype 2 infection in Aedes albopictus. Arch. Virol. 159, 3053-3057. doi: 10.1007/s00705-014-2051-1

Xue, R. D., Edman, J. D., and Scott, T. W. (1995). Age and body size effects on blood meal size and multiple blood feeding by Aedes aegypti (Diptera: Culicidae). J. Med. Entomol. 32, 471-474. doi: 10.1093/jmedent/32. 4.471

Young, P. R. (2018). Arboviruses: a family on the move. Adv. Exp. Med. Biol. 1062, 1-10. doi: 10.1007/978-981-10-8727-1_1

Zhang, X., Sun, L., and Rossmann, M. G. (2015). Temperature dependent conformational change of dengue virus. Curr. Opin. Virol. 12, 109-112. doi: 10.1016/j.coviro.2015.04.006

Zouache, K., and Failloux, A. B. (2015). Insect-pathogen interactions: contribution of viral adaptation to the emergence of vector-borne diseases, the example of chikungunya. Curr. Opin. Insect Sci. 10, 14-21. doi: 10.1016/j.cois.2015. 04.010

Zouache, K., Fontaine, A., Vega-Rua, A., Mousson, L., Thiberge, J. M., LourencoDe-Oliveira, R., et al. (2014). Three-way interactions between mosquito population, viral strain and temperature underlying chikungunya virus transmission potential. Proc. Biol. Sci. 281:20141078. doi: 10.1098/rspb.2014. 1078

Zouache, K., Raharimalala, F. N., Raquin, V., Tran-Van, V., Raveloson, L. H., Ravelonandro, P., et al. (2011). Bacterial diversity of field-caught mosquitoes, Aedes albopictus and Aedes aegypti, from different geographic regions of Madagascar. FEMS Microbiol. Ecol. 75, 377-389. doi: 10.1111/j.1574-6941. 2010.01012.x

Conflict of Interest: The authors declare that the research was conducted in the absence of any commercial or financial relationships that could be construed as a potential conflict of interest.

Copyright (C) 2020 Bellone and Failloux. This is an open-access article distributed under the terms of the Creative Commons Attribution License (CC BY). The use, distribution or reproduction in other forums is permitted, provided the original author(s) and the copyright owner(s) are credited and that the original publication in this journal is cited, in accordance with accepted academic practice. No use, distribution or reproduction is permitted which does not comply with these terms. 